\title{
Transfer Function Development for Control of Cathode Airflow Transients in Fuel Cell Gas Turbine
}

\section{Hybrid Systems}

Nana Zhou ${ }^{\mathrm{a}, \mathrm{b}, *}$, Chen Yang ${ }^{\mathrm{a}, \mathrm{b}}$, David Tucker $^{\mathrm{c}}$, Paolo Pezzini $^{\mathrm{c}}$, Alberto Traverso $^{\mathrm{d}}$

${ }^{a}$ Key Laboratory of Low-grade Energy Utilization Technologies and Systems, Ministry of Education, Chongqing400030, China

${ }^{\mathrm{b}}$ College of Power Engineering, Chongqing University, Chongqing400030, China

'US. Department of Energy, National Energy Technology Laboratory, Morgantown, West Virginia26507, U.S.A.

dThermochemical Power Group (TPG) - DIME, Università di Genova, Genova16145, Italy

*Corresponding author. Tel.: +1-304-777-7557; fax: +1-304-285-0903; E-mail address: zhounana.cqu@gmail.com (Nana Zhou) 


\begin{abstract}
Direct-fired fuel cell gas turbine hybrid power system response to open-loop transients were evaluated using a hardware-based simulation of an integrated solid oxide fuel cell gas turbine (SOFC/GT) hybrid system, implemented through the Hybrid Performance (Hyper) facility at the U.S. Department of Energy, National Energy Technology Laboratory (NETL). A disturbance in the cathode inlet air mass flow was performed by manipulating a hot-air bypass valve implemented in the hardware component. Two tests were performed; the fuel cell stack subsystem numerical simulation model was both decoupled and fully coupled with the gas turbine hardware component. The dynamic responses of the entire SOFC/GT hybrid system were studied in this paper. The reduction of cathode airflow resulted in a sharp decrease and partial recovery of the fuel cell thermal effluent in 10 seconds. In contrast, the turbine rotational speed did not exhibit a similar trend. The transfer functions of several important variables in the fuel cell stack subsystem and gas turbine subsystem were developed to be used in the future control method development. The importance of the cathode airflow regulation was quantified through transfer functions. The management of cathode airflow was also suggested to be a potential strategy to increase the life of fuel cells by reducing the thermal impact of operational transients on the fuel cell subsystem.
\end{abstract}

Keywords: Solid oxide fuel cell; Gas turbine; Hybrid system; Hardware-in-the-loop simulation; Transients; Transfer function 


\section{Introduction}

The hybrid system combined of the fuel cell stack and a gas turbine has the greatest potential for high efficiency and flexibility of fuels [1]. The U.S. Department of Energy, National Energy Technology Laboratory designed and developed a hybrid performance (HyPer) facility using hardware-in-the-loop simulation (HILS) [2]. Hardware driven by a 1-D, distributed, real-time SOFC model was interfaced with a gas turbine hardware system, taking advantage of the flexibility associated with numerical models and the fidelity associated with hardware systems [3]. The HyPer facility was designed to examine fundamental issues related to component integration, to analyze steady operation and transient responses, to demonstrate critical operability issues, and to support novel controls development relevant to advanced power systems.

These two subsystems were highly coupled, and the fuel cell transient performance could affect the gas turbine response in a matter of seconds, resulting in many complicated control issues. Examples would include: the start-up and shutdown of the hybrid system [4-6], the load trip and part load performance of the fuel cell system [7-10], compressor stall and surge [11-15], fuel composition change $[16,17]$ and degradation $[18,19]$ etc.

Also, thermal management was shown to be a critical issue in the operation of fuel cell systems and have a large impact on performance and reliability [3, 20-23]. Cathode inlet airflow was a key factor in maintaining the desired cell temperatures efficiently. If the operating temperature is too low, the ohmic losses rise, decreasing cell performance and aggravating the degradation. However, if the temperature is too high, interconnect materials become too costly. Modulation of the cathode airflow also provided the possibility to be used as a control variable to increase the fuel cell life time.

The system dynamic response to the cathode inlet airflow transients by increasing and decreasing a hot-air bypass valve opening implemented in the hardware component as shown in Fig. 1 is presented in this paper. Dynamic response in hardware system variables and fuel cell simulation parameters are also discussed. The transfer functions of several key parameters are summarized and the requirement of a more reliable control method is elicited in this work. The potential of using cathode inlet airflow in the new control systems to mitigate the impact of some other specific transients is also addressed in this paper. 


\begin{tabular}{|llll|}
\hline \multicolumn{2}{|l|}{ Nomenclature } & Acronyms & \\
$e_{\text {max }}$ & maximum perturbation allowed & $S O F C$ & solid oxide fuel cell \\
$F$ & Faraday's constant, Coulombs $\mathrm{mol}^{-1}$ & $G T$ & gas turbine \\
$G$ & Gibbs free energy, $\mathrm{kJ}$ & $L H V$ & lower heating value, $\mathrm{kJ} \mathrm{kg}^{-1}$ \\
$k$ & transfer function gain & $N G$ & natural gas \\
$p$ & pressure, $\mathrm{kPag}$ & $H I L S$ & hardware-in-the-loop simulation \\
$\dot{Q}$ & thermal effluent from fuel cell, $\mathrm{kW}$ & & \\
$R_{u}$ & universal gas constant, $\mathrm{J} \mathrm{mol}^{-1} \mathrm{~K}^{-1}$ & Subscripts and superscripts \\
$t_{d}$ & dead time, $\mathrm{s}$ & act & activiation \\
$T$ & temperature, $\mathrm{K}$ & cell & fuel cell \\
$V$ & voltage, $\mathrm{V}$ & dif & diffusion \\
$\bar{y}$ & unscaled process variable & air & air in the fuel cell cathode \\
$\bar{y}_{\text {nominal }}$ & nominal value of the unscaled process variable & solid & solid part of the fuel cell cathode \\
$\tau$ & time constant, s & & \\
$\eta$ & losses & & \\
\hline
\end{tabular}

\section{HyPer facility description}

The HyPer facility was designed based on the concept of SOFC/GT topping cycle, in which the fuel cell subsystem was placed upstream of the turbine. The combination of the physical, high cost of fuel cell stack was prohibitive. Thus, mathematic simulations of SOFC stack were used to explore the hybrid systems by driving the hardware representation. The hardware representation included two pressured vessels, representing the air manifold, residence time, and the flow impedance in fuel cell cathode side; a post combustor that was used to simulate the thermal effluent from the fuel cell stack numerical model.

The particular configuration of the HyPer facility is illustrated in the diagram shown in Fig. 1. The components shown in the dash box and the fuel valve model represent the virtual fuel cell subsystem, while the combustor (V-302) and the pressure vessels (V-301 and V-304) are hardware components representing the fuel cell system that are physically coupled to the balance of plant hardware [5, 24].

The ambient air was compressed to a pressure ratio near 4 in the compressor (C-100), which was on a single shaft with the turbine and the generator (G-102). Then the compressed air was discharged into two ports. The primary port passed through two surface recuperators (E-300 \& E-305) as the cold side; the other port was routed to the bleed air which was directed to the atmosphere and the cold air which was diverted to post combustor mixing volume (V-304) directly, bypassing other components. 
Leaving the two heat exchangers, the main flow entered the fuel cell cathode simulator hardware system: the air plenum (V-301); the natural gas combustor (V-302); the post-combustor mixing volume V-304. The rest of the airflow directed to V-304 through the hot-air valve (FV-380), circumventing the air plenum and the combustor. The gas turbine (T-101) was used to recover the waste energy in unutilized fuel from the solid oxide fuel cell stack. Then the airflow was routed to the gas turbine to produce power and drive the compressor. The turbine exhaust went to the hot side of the heat exchangers, where the thermal energy was recovered before being exhausted to the atmosphere.

The pressure, temperature, and mass flow of the airflow before V-301 were measured and fed to the 1-D, real time SOFC model. The thermal effluent of the real time SOFC stack simulation, $\dot{Q}$, was converted to the amount of fuel flow to control the fuel valve (FV-432) dynamically, ensuring that the output of V-302 is equivalent to the thermal effluent of fuel cell stack.

\subsection{Hardware system}

The entire hardware system in HyPer facility occupied a space of $6.1 \mathrm{~m} * 7.6 \mathrm{~m} * 7.2 \mathrm{~m}$. The inputs of the hardware system were the compressor intake and fuel flow through FV-432, which was the only energy input to the entire hardware system. The system could be operated with the fuel cell stack subsystem decoupled from the hardware system. Under these circumstances, the fuel valve was controlled by a PID controller to maintain the turbine speed at the nominal speed. In the HILS of this study, FV-432 was controlled by the SOFC model output.

\subsubsection{Auxiliary Power Unit (C-100, T-101, G-102)}

The Auxiliary Power Unit (APU) consisted of a direct coupled turbine, with a nominal operating speed of 40,500 rpm, a dual-stage radial compressor and a synchronous, gear driven generator in a single shaft. The generator was loaded by an isolated resistor bank (E-105), via electrical resistance with a practical range of 0-75 $\mathrm{kW}$ electrical load.

Gas turbine rotational speed was measured by an optical sensor (ST-502). The sample time step of the optical sensor was 0.005 seconds and there was $0.12 \%$ relative error in the precision of the measurement. It was an extremely critical variable in the hybrid system and needed to be considered sufficiently. The range of operability of turbine speed was between 38,500 and 42,000 rpm. When the turbine speed exceeded the limitations, the system would be automatically shut down through the Emergence Shutdown (ESD) control strategy for safety [15]. 
Total system pressure drop (PDT-158) was measured as the pressure difference between the compressor discharge and the turbine inlet. It was one of the critical parameters used to characterize the system performance. Minimization of losses throughout the system contributed to more efficient operation.

\subsubsection{Heat exchangers (E-300 and E-305)}

Two counter flow primary surface heat exchangers were used in parallel in this facility to recuperate heat from the turbine exhaust and import it to the compressor discharge air.

\subsubsection{Pressure vessels (V-301, V-302 and V-304)}

The pressure vessels and associated process air piping were used to provide a physical representation of the fuel cell air manifold and the cathode volume, the thermal characteristics of the effluent and the post combustion volume. Additionally, the vessels and piping primarily represented the residence time of pressure transients associated with the compressed air volume and the flow impedance that would exist in a real fuel cell stack of a hybrid system

The flow conditions to the plenum V-301 were measured to represent the live cathode inlet airflow value of the fuel cell stack numerical model. An annubar flow meter (FT-380) was used to measure the cathode inlet airflow, the air pressure was measured in PT-305 and the air temperature was measured using TE-326. The transients addressed in this paper are cathode inlet air mass flow changes, targeted by the step changes in hot-air bypass valve.

\subsubsection{Bypass valves (FV-162, FV-170, FV-380)}

HyPer facility was designed with three valved bypasses for the management of cathode airflow rate in fuel cell stacks, the avoidance of compressor surge in turbomachinery, and the development of novel control methods in SOFC/GT hybrids [25].

The bleed-air bypass valve (FV-162) was used to discharge the cold compressed air into the atmosphere, which increased the stall margin but decrease the turbine efficiency;

The cold-air bypass valve (FV-170) was used to route the compressed air from the compressor discharge directly into the turbine inlet through the post combustor volume. The cold-air bypass valve was also very effective for the avoidance of compressor surge.

The hot-air bypass valve (FV-380) was used to extract the airflow after the heat exchangers and divert it directly into the turbine inlet, bypassing the fuel cell stack simulator air plenum, piping and combustion volume. The manipulation of the hot-air 
bypass valve had the least effect on the hardware system. The cathode airflow transient addressed in this paper was targeted by the manipulation of FV-380.

\subsubsection{Swift fuel valve (FV-432)}

A high-speed electromechanical valve (FV-432) was used to manipulate the fuel flow to the post combustor, which was the only energy input to the whole hardware system. The fuel valve could either be controlled by a PID controller to maintain the turbine speed in the nominal state (closed loop), or commanded by the fuel cell model live output in real time to replicate the thermal effluent from the fuel cell system (open loop).

\section{2 Software system}

For the avoidance of destroying the expensive solid oxide fuel cell stack subsystem, a 1-D, distributed, real-time operating fuel cell model and other supporting components were built in Matlab-Simulink ${ }^{\mathrm{TM}}$ and integrated into the HyPer facility through dSpace ${ }^{\mathrm{TM}}$ control desk, utilizing the hardware-in-the-loop simulation approach. The configuration of the fuel cell stack subsystem model is shown in the dash box in Fig. 1.

\subsubsection{1-D real-time fuel cell model}

The model was manipulated by setting adjustable user inputs, such as fuel cell current demand, number of cells, cathode airflow conditions and anode fuel flow conditions. The outputs of the model included the voltage, fuel utilization, cathode/anode outlet conditions and internal profiles.

The model was built based on one single cell, scaling by the number of cells to obtain the overall conditions of the fuel cell stack. Each cell was divided into 20 nodes along the length of the SOFC. Temperature profiles, Nernst profiles, current density profiles, composition profiles and heat generation profiles etc. were all based on each node in the cathode channel. The variables used in this paper were the average values of the 20 nodes.

The operating cell voltage was calculated subtracting the polarization losses produced activation, ohmic and diffusion losses at the triple phase boundary interface for the anode and cathode from the Nernst potential, shown in Eqs. (1)-(2).

$$
\begin{aligned}
& V_{\text {cell }}=V_{\text {Nernst }}-\eta_{\text {dif }}-\eta_{\text {act }}-\eta_{\text {ohm }} \\
& V_{\text {Nernst }}=-\frac{\Delta G_{\mathrm{H}_{2} \mathrm{o}}^{0}}{2 F}+\frac{R_{u} T}{2 F} \ln \left(\frac{p_{\mathrm{H}_{2} \mathrm{o}} p_{\mathrm{O}_{2}}^{\frac{1}{2}}}{p_{\mathrm{H}_{2} \mathrm{o}}}\right.
\end{aligned}
$$


A modified method found in some other literature was used to calculate the diffusion polarization [26]. The BulterVolmer equation was simplified into an explicit equation for activation losses [27]. The ohimc polarization term considered only the PEN structure, assuming the resistance of the interconnect material was relatively low in comparison. More details about the fuel cell model have been presented in previous work [28].

\subsubsection{Fuel cell stack subsystem model}

As shown in Fig. 1, besides the 1-D, distributed, real-time operating fuel cell stack model, the simulated subsystem also consisted of a heat exchanger model and a post-combustor model

For integration with the HyPer hardware, the cathode airflow conditions could also use the live value measured before V301 besides the adjustable user inputs. Before feeding to the fuel cell stack model, the air was preheated in the heat exchanger to ensure a reasonable cathode inlet air temperature. After the reaction inside the fuel cell, the cathode and anode outputs were routed into the post combustor model to combust the unutilized fuel, and then the exhaust was directed to the heat exchanger as the hot side. The thermal effluent $\dot{Q}$ from the fuel cell simulation subsystem was calculated as the change in enthalpy between the measured input airflow (heat_air_in) and the simulated outlet airflow (heat_air_out) to predict the thermal energy transferred to the airflow from the electrochemical reaction, materials inside the fuel cell system and the combustion of unutilized fuel. It was the key variable for the communication between the hardware system and the software system.

Generally, the limitations on the size of stack capable of being simulated were $200 \mathrm{~kW}$ to $700 \mathrm{~kW}$, determined by the turbomachinery hardware of the HyPer facility.

\section{3 Hardware-in-the-loop simulation}

In HyPer facility, three components, V-301, V-302, V-304, were used as the hardware simulators of the entire fuel cell stack subsystem. The thermal effluent from the fuel cell subsystem, $\dot{Q}$, was converted to the amount of fuel flow which predicted the extra energy needed to be added in the airflow, and then dynamically commanded the swift fuel valve FV-432. This was the only energy input to the hardware system and driven by the real time simulation output, representing the thermal energy exiting from the fuel cell stack.

The fuel cell stack subsystem was integrated to the gas turbine subsystem through hardware simulator. During the operation of HILS, the two subsystems were fully coupled; the fuel cell model was responding to the live measured cathode inlet airflow conditions and the simulation output $\dot{Q}$ was dynamically controlling the thermal energy entering the entire system. 
The application of HILS to a physical gas turbine paired with a modeled fuel cell stack subsystem through hardware, used in the HyPer facility in NETL, showed the great capability to reconcile the shortcomings and advantages of numerical models and hardware systems. The HyPer possessed the ability to assess system performance under various operating conditions. It also aimed to evaluate novel control methods during various transients and accurately identify the non-intuitive interactions between the SOFC stack and the GT. This configuration of the HyPer facility was unique because it allowed the examination of coupled electrochemical transient impact on the compressor dynamics without the risk of destroying the expensive real fuel cell stack.

\section{Experimental method}

\subsection{Test procedure}

After start-up, a PID controller was used to ramp up the fuel flow to the post combustor in order to achieve the nominal turbine speed. The system took around an hour to reach the steady state due to the large thermal capacitance of the post combustor mixing volume. In the meantime, the fuel cell model was run in the dSpace platform to reach the stead state.

\subsubsection{Implementation of HILS}

First, the turbine hardware system and the fuel cell simulation model were operated seperately until both of them reached the steady state. The model was utilizing the live measured cathode inlet airflow conditions while the physical fuel flow to the post combustor was still controlled by a PID controller to maintain the turbine speed constant. A virtual fuel valve position was calculated according to the thermal effluent from the fuel cell stack. Then, several tunable variables in both hardware and software, like electrical load, bypass valves, fuel cell load and number of cells, etc., were adjusted for the approximate equivalent of the calcaluted fuel valve opening and the real time fuel valve position. This guaranteed a smooth transition. The switch from the closed loop to the HILS was operated in the control platform by the operator. The fuel valve was switched from PID controller to the fuel cell subsystem model-in-control. Then the numerical and physical systems were fully coupled for a HILS system: the model was responding to the live measured airflow conditions, and the hardware system was driven by the thermal effluent from the fuel cell stack subsystem.

More details about the implementation of HILS to the HyPer facility was included previously in other work [29]. Table 1 lists the essential parameter values of the fuel cell stack subsystem simulation model and the hardware system before being switched to the HILS. 


\subsubsection{Test plan}

To determine the change extent of cathode inlet airflow by adjusting the hot-air bypass valve opening, several scoping tests were performed prior using HILS. The system status and fuel cell stack parameters were set as shown in Table 1. The fuel cell stack model was fully coupled with the hardware system and the fuel valve FV-432 was dynamically controlled by the output of the fuel cell stack subsystem model. The initial value of the hot-air bypass valve was $30 \%$ open. Then $32 \%, 35 \%$, 38\% and $50 \%$ open were commanded to the hot-air bypass valve. By observing the system dynamic response, especially the turbine speed, and the compressor surge margin map, 50\% open was selected as the final opening for the following tests. Two comparable sets of tests were conducted in this work:

Coupled Test: The HILS was applied to the HyPer system. The fuel valve was controlled by the fuel cell model output in real time to evaluate the impact of electrochemical transient on the hybrid system. The entire system was in the open loop, and no controller was used in this set of test.

Decoupled Test: The fuel flow to the hardware system was set constant as the value shown in Table 1 to determine the effect of hot-air bypass valve FV-380 on the turbine speed without fuel cell simulation under the same test conditions as above. No controller was used in this part.

In each set, the hot-air bypass valve was commanded from $30 \%$ open to $50 \%$ open. Fifteen minutes later, the hot-air bypass valve was set back to $30 \%$ open. The test procedure was summarized in Table 2.

\subsection{Transfer functions development}

Transfer functions of some critical variables were developed and comparisons between each case were also presented. The coupling between the fuel cell and the turbine could be studied by developing empirical transfer functions, to capture the dynamic from hot-air valve change to turbine speed. For simplicity, all empirical transfer functions of higher order are generally approximated as First Order Plus Delay Time (FOPDT) as shown below:

$$
G(s)=\frac{k \cdot e^{-t_{d} \cdot s}}{(\tau \cdot s+1)}
$$

Where the gain, $k$, is the ratio between the change in process variable and the change in the actuator input; the time constant, $\tau$, represents $63 \%$ of the new steady state change, and finally, $t_{d}$, is the dead time, the period of time when a significant change in the input does not affect the output.

Before computing each transfer function a scaling approach was used for each process variable, using the following rule:

$$
y=\frac{\bar{y}-\bar{y}_{\text {nominal }}}{e_{\max }}
$$


The transfer functions for several important parameters in both hardware and software were developed in this paper, including cathode mass flow, turbine speed, thermal effluent, total system pressure drop, cathode inlet temperature, change in energy dissipation, and the temperature difference between air and solid in cathode side. The nominal value and the maximum perturbation allowed by a hypothetical controller implementation are shown in Table 3 .

\section{Results and discussions}

The response of cathode inlet airflow in both directions: decreasing when the hot-air valve was changed from $30 \%$ open to $50 \%$ open, increasing when the hot-air valve was changed from $50 \%$ open to $30 \%$ open, were both discussed below. The transfer functions were developed for both steps in coupled and decoupled tests. The time " 0 " in each chart is the time when the step change, hot-air bypass valve transient in this paper, was performed.

\section{Cathode Mass Flow}

The hot-air bypass valve was designed to control the cathode air mass flow with the aim to control the fuel cell temperature. The cathode airflow responses in each case of the tests are already shown in Table 2 . The normalized value of the cathode airflow change is illustrated in Fig. 2.

The normalized values of the cathode airflow change when opening the hot-air bypass valve from $30 \%$ to $50 \%$ open are shown in Fig. 2a and Fig. 2b. To show the overall response, the data in Fig. 2a was from 100 seconds before the transient to 900 seconds after the transient for each set. For the observation of the rapid response during the transient, the data in Fig. $2 \mathrm{~b}$ was from 5 seconds before the transient to 40 seconds after the transient for each set. It is shown that the opening of the hot-air valve resulted in the reduction of cathode inlet airflow immediately. In the decoupled test, the cathode inlet airflow decreased from 0.78 $\mathrm{kg} / \mathrm{s}$ to $0.58 \mathrm{~kg} / \mathrm{s}$ based on the actual construction of the hardware system. However, the coupling of fuel cell model caused a slight greater reduction in cathode mass flow because of the decreasing of the turbine speed.

Correspondingly, Fig. 2c and Fig. 2d are the normalized values of the cathode airflow change when closing the hot-air bypass valve from $50 \%$ to $30 \%$ open. An instant increase was observed in the cathode air mass flow. Likewise the coupled test showed a greater increase in cathode inlet airflow than the decoupled test as anticipated.

It is demonstrated that the hot-air valve had a strong effect on the cathode inlet airflow as designed.

The transfer functions of the coupled tests when opening the bypass valve and closing the bypass valve are shown in Eq. (5) and Eq. (6). The transfer function shown in Eq. (5) indicates that in just 1.6 seconds the cathode airflow achieved 63\% of the 
variation and the dead time is about 0.4 seconds. A similar result is observed in the opposite direction, as seen in Eq. (6). The time constant is 2 seconds and the dead time is about 0.6 seconds.

$$
\begin{aligned}
& G_{1}(s)=\frac{-0.03 e^{-0.4 s}}{(1.6 s+1)} \\
& G_{2}(s)=\frac{-0.0275 e^{-0.6 s}}{(2 s+1)}
\end{aligned}
$$

The transfer functions of the decoupled tests when opening the bypass valve and closing the bypass valve are also computed in Eq. (7) and Eq. (8). $G_{3}(s)$ shows that the cathode airflow achieved $63 \%$ of variation in 1.3 seconds while the dead time is 0.5 seconds.

$$
\begin{aligned}
& G_{3}(s)=\frac{-0.025 e^{-0.5 s}}{(1.3 s+1)} \\
& G_{4}(s)=\frac{-0.0225 e^{-0.7 s}}{(2.1 s+1)}
\end{aligned}
$$

Since many of the trends for valve opening and closing were observed to be proportionally inverse, only the data obtained in one direction was discussed in detail. However, the transfer functions for all cases were obtained and summarized in Table 4.

\section{$\underline{\text { Turbine Rotational Speed }}$}

As illustrated in Fig. 3, the variation of the turbine speed in decoupled test was insignificant. Hot-air bypass opening did not affect the turbine speed when the fuel cell model was not coupled in the loop. Conversely, the HILS test indicated a strong coupling between the cathode airflow and the turbine speed. A 30\% change in cathode airflow reduction resulted in a change of $1000 \mathrm{rpm}$ in turbine speed in just ten seconds. The decrease in turbine speed was a consequence of the reduction in thermal effluent from the fuel cell model.

As shown in Fig. 3, no transfer function could be developed for the decoupled test when opening the hot-air bypass valve because the turbine speed was not a function of hot-air bypass operation when the fuel cell model was not coupled in the loop. Eq. (9) is the transfer function of the turbine speed for the coupled test. It shows that the turbine speed achieved the $63 \%$ of variation in just 4 seconds and that the dead time was only about 1.6 seconds. The huge and immediate impact of the existence of the fuel cell in the loop on the hardware could be concluded. A similar result in the opposite direction was observed. From 50\% to $30 \%$ of the bypass opening, the time constant was 3 seconds and the dead time about 1.4 seconds. 


$$
G_{5}(s)=\frac{-0.02 e^{-1.6 s}}{(4 s+1)}
$$

\section{Thermal Effluent}

During the hot-air bypass operation, the thermal effluent coming out of the fuel cell, $\dot{Q}$, is a critical parameter. Figure $4 \mathrm{a}$ shows the thermal effluent change and an enlargement of the time scale for the transients is shown in Fig. 4b. For comparative purposes, the turbine speed changes are also shown in the charts. Because in the decoupled test, the fuel cell model was not coupled with the hardware system, all the data shown in Fig. 4 were from the coupled test.

Due to the instant reduction of cathode airflow, the thermal effluent had a sharp decline within three seconds after the step change and then recovered by $50 \%$ of the initial change within ten seconds. Because the fuel valve FV-432 was commanded by the thermal effluent, the change in thermal effluent strongly affected the turbine speed. As described above, the compressor was driven by the turbine on a single shaft. The decrease in turbine speed resulted in a corresponding change in compressor intake and then cathode inlet air mass flow. It was demonstrated that the cathode air mass flow decreased more in coupled test than decoupled test when the same changes were implemented in hot-air bypass valve, as illustrated in Fig. 2b.

Although the controlling $\dot{Q}$ directly affected the turbine speed, the turbine speed did not show the same discontinuity at 3 seconds after the transient as shown in Fig. 4b. The rotational inertia of the turbine and electrical load was thought to oppose the sudden changes in thermal energy.

The transfer functions for the thermal effluent were also developed in Eq. (10). In order to characterize the thermal effluent accurately, the transfer functions have been split into two sections, the first reduction trend up to three seconds and the second increase trend from three seconds onward.

$$
G_{6 a}(s)=\frac{-0.025 e^{-1.1 s}}{(1.6 s+1)} ; \quad G_{6 b}(s)=\frac{0.0015 e^{-0.4 s}}{(5.6 s+1)}
$$

The transfer function $G_{6 a}$ shows a very fast dynamic; $63 \%$ of its reduction was achieved in 1.6 seconds, with a dead time of 1.1 seconds. Instead, the transfer function $\mathrm{G}_{6 \mathrm{~b}}$ showed a slower dynamic, the $63 \%$ of the variation was achieved in 5.6 seconds, with a dead time of 0.4 seconds. As described in Fig. 4a, the thermal effluent behavior strongly affected turbine speed.

\section{$\underline{\text { Total System Pressure Drop }}$}


In both situations, the total system pressure drop was very small but more significant when the fuel cell model was in the loop. The system pressure loss in the coupled test was observed to decrease by $3 \mathrm{kPag}$ while the system pressure loss decreased by $1.8 \mathrm{kPag}$ in the decoupled test shown in Fig. 5 . The electrochemical and thermal response of the fuel cell reduced the pressure loss in the whole system. They both led to the corresponding changes in system temperatures and pressures.

The transfer functions of the total system pressure drop for both coupled and decoupled tests are shown in Eq. (11) and Eq. (12) respectly. In the coupled test, the turbine speed achieved the $63 \%$ of the new steady-state value in just 2.5 seconds, and that the dead time is about 0.5 seconds. While in the decoupled test, the time constant is 1.6 seconds and the dead time 0.1 seconds.

$$
\begin{aligned}
& G_{7}(s)=\frac{-0.027 e^{-0.4 s}}{(2.5 s+1)} \\
& G_{8}(s)=\frac{-0.017 e^{-0.1 s}}{(1.6 s+1)}
\end{aligned}
$$

\section{$\underline{\text { System Pressures }}$}

Figure 6 shows the comparison of transients in compressor outlet pressure, cathode inlet pressure, and turbine inlet pressure. In the coupled test shown in Fig. 6a, all these three pressures decreased right after the step change and then started recovering in response to the turbine speed change. Likewise, the three pressures exactly followed each spike of the turbine speed. It also indicated that the volatility of the turbine speed was not resulted from the noise but illustrated the physical change of the turbine speed. The pressures did not show significant changes according to the turbine speed response for the decoupled results shown in Fig. 6b.

\section{$\underline{\text { System Temperatures }}$}

The responses of cathode inlet air temperature and turbine inlet air temperature to the hot-air valve trip are shown in Fig. 7. For the coupled test in Fig. 7a, the turbine inlet temperature change exactly followed the thermal effluent transient as expected. The cathode inlet temperature showed a gradual decrease, resulting from the decline of the turbine outlet temperature and the decrease of the compressor discharge airflow. While in the decoupled test shown in Fig. $7 b$, the fuel valve FV-432 was set constant, and the compressor discharge airflow did not show obvious change. Thus the response of cathode inlet temperature and turbine inlet temperature were the consequences of the total system drop.

The transfer functions of the cathode inlet air temperatures transients in the coupled test and the decoupled test are shown in Eq. (13) and Eq. (14). The dead time of the coupled test and decoupled test were both 2 seconds. However, comparing 
with the transfer functions of other variables, the time constants were both much greater, 45 seconds in the coupled test and 60 seconds in the decoupled.

$$
\begin{aligned}
& G_{9}(s)=\frac{-0.0235 e^{-2 s}}{(45 s+1)} \\
& G_{10}(s)=\frac{-0.025 e^{-2 s}}{(60 s+1)}
\end{aligned}
$$

\section{Change in Dissipation of Thermal Energy in Fuel Cell}

Stainless steel 441 (SS441) was used as the interconnect material in the fuel cell system, which was integrated with a gas turbine and other associated components in the HyPer facility [30]. The temperature dependent specific heat capacity and thermal conductivity were presented for SS441 on a temperature range of $300 \mathrm{~K}-1500 \mathrm{~K}$ in previous work [31].

The fuel cell stack used in this work was operated at around $1073 \mathrm{~K}$. The specific heat of the fuel cell stack is approximately $0.7 \mathrm{~kJ} /(\mathrm{kg} * \mathrm{~K})$. The mass of each cell including the connection part of $1.4 \mathrm{~kg}$ and 2000 cells were used in the tests. Thus, the total mass of the fuel cell stack used was $2800 \mathrm{~kg}$. The total heat capacity of the fuel cell stack was equivalent to the product of the specific heat and the stack mass, of $1960 \mathrm{~kJ} / \mathrm{K}$.

The transient in the cathode air mass flow did not affect the electrochemical reactions inside the fuel cell very much. Thus the change in the dissipation of thermal energy was thought to be the major reason of the thermal effluent change. Figure 8a shows the change in the dissipation as a function of time and the enlargement of the time scale around the fast change is shown in Fig. 8b. The reduction of cooling airflow results in a dramatic reduction in the dissipation of thermal energy over the first five seconds, while $55 \mathrm{~kW}$ of thermal energy was stored in the solid. However, because of the huge mass and active area in the solid side, no significant solid temperature increase was observed in Fig. 9a. The temperature difference between the solid and gas temperature narrowed, reducing the heat flux between the solid and the gas and resulting in the decline of the thermal energy dissipation. Afterwards, the temperature difference increased gradually, the heat flux decreased until a new steady state was achieved.

The transfer function of the thermal energy dissipation spike was computed and shown in Eq. (15). The dead time is 0.6 seconds and the variable finished its $63 \%$ change in 1.4 seconds.

$$
G_{11}(s)=\frac{0.025 e^{-0.6 s}}{(1.4 s+1)}
$$

\section{Differential Temperature}


Figure 9a illustrates the average air temperature, average solid temperature inside the cathode side and the differential temperature between them, $\Delta \mathrm{T}$. As discussed above, during hot-air bypass operation, the differential temperature shows a critical behavior. Normalized values of the average air temperature, average solid temperature inside the cathode side and the differential temperature are plotted in Fig. $9 \mathrm{~b}$.

As the thermal effluent, in order to characterize the $\Delta \mathrm{T}$ accurately, the transfer functions were split into two sections: the first reduction trend and second increase trend, shown in $G_{12 a}$ and $G_{12 b}$ respectively.

$$
G_{12 a}(s)=\frac{-0.023 e^{-0.5 s}}{(1.6 s+1)} ; \quad G_{12 b}(s)=\frac{0.017 e^{-8 s}}{(125 s+1)}
$$

\section{$\underline{\text { Multiple Variables }}$}

Several important variables responses were plotted in Fig. 10a to characterize the thermal effluent transient. Figure 10b illustrates the normalized values of these selected variables. As described before, $\dot{Q}$ is calculated as the enthalpy change between the measured input airflow and output airflow. The input air temperature was a measured value by TE-326 while the outlet air temperature was a calculated value from the fuel cell stack subsystem model. $\Delta \mathrm{T}$ was already addressed above in Fig. 9a. The red line indicates the cathode inlet airflow measured by FT-380, which was also the target variable in this paper.

As discussed above, the reduction of cathode inlet airflow and $\Delta \mathrm{T}$ resulted in the sharp decrease in $\dot{Q}$. Due to the drop of the thermal effluent, the fuel entering the hardware system decreased. The turbine inlet temperature decreased accordingly and the turbine speed also reduced in response. Thereby the cathode inlet air temperature decreased, leading to a further impact in the system.

After the third second, the cathode airflow remained quite constant. The drop of the cathode inlet air temperature made the heat_air_in have a slight decline. While the continuous increase of model output air temperature and the recovery of $\Delta \mathrm{T}$ caused a greater increase in heat_air_out. As a consequence, the $\dot{Q}$ was recovered by $50 \%$ of the initial loss in seven seconds. It is

shown in Fig. 8a and Fig. 9a that the $\dot{Q}$ change was mainly dominated by the heat dissipation and $\Delta \mathrm{T}$ between the air temperature and the solid temperature.

\section{Other Parameters in Fuel Cell}


The fuel utilization kept fairly constant, approximately 54.2\%, shown in Fig. 11 by the red line. The reduction of cathode inlet airflow caused a $0.004 \mathrm{~V}$ decline in cell voltage and $2 \mathrm{~kW}$ decline in stack power. The changes in the cell voltage and stack power are quite minor, comparing with the change in the hardware system variables.

\section{Summary}

Table 4 summarizes all the transfer functions in decoupled tests and couple tests when opening and closing the hot-air bypass valve. Table 5 shows the dead time for each transfer function ordered from shortest to longest. All the time constant values are shown in Table 6. In Table 5, it was intuitively illustrated that the total system drop changed immediately after the bypass valve was moved, and followed by the cathode airflow change. Then a sharp instant change in the differential temperature between the air and the solid resulted from the cathode airflow transient. It caused a corresponding change in the dissipation of thermal energy in the fuel cell within a very short time. The thermal effluent from the fuel cell model $\dot{Q}$ was a consequence of all the responses mentioned above, which drove the fuel flow going to the hardware system and thereby strongly affected the turbine speed. Afterwards, the temperatures in the hardware system were affected due to the fuel flow change, but the responses were much slower.

The transient of the cathode airflow caused an instant and rapid change in the heat flow transferred between the gas and the solid inside the fuel cell system, resulting in a huge change in the turbine speed and other variables. Therefore, the cathode airflow was demonstrated to be a considerably critical parameter in terms of thermal management, which needed to be considered sufficiently.

\section{Conclusion}

Cathode airflow transients were evaluated using a hardware-in-the-loop simulation approach. A bypass valve was used to implement a change in cathode airflow for both coupled (fuel cell in the loop) and decoupled (without fuel cell simulation) tests. A comparison of the tests showed that the electrochemical response in the coupled case significantly affected the system performance, while the decoupled case without the fuel cell in the loop resulted in very little impact to system performance.

A $30 \%$ change in cathode airflow resulted in a 1,000 rpm change in turbine rotational speed within just 10 seconds. Within five seconds of the transient, the change in thermal energy dissipation reached $55 \mathrm{~kW}$. System pressure drop, fuel cell gas 
temperature, turbine inlet temperature, exhaust gas temperature, and all the system pressures exhibited rapid responses to the airflow transient. The dynamic response of the system parameters were characterized for a step change in cathode airflow to develop transfer functions, mapping the response at the nominal operating state.

An analysis of the dead time for each transfer function provided a quantitative method for determining the chronological order of events occurring from the initiation of the transient. As the bypass valve was opened or closed, a change in the system pressure drop occurred in as little as $100 \mathrm{~ms}$, driving the rest of the system response. The heat transfer between the gas and the solid inside the fuel cell cathode in response to the cathode cooling air transient was demonstrated to be a considerably fast process, with a $600 \mathrm{~ms}$ dead time, and affected the thermal effluent of the fuel cell about one second after the transient. A summary of system transfer functions with tables of dead times and time constants was assembled in the paper.

Although the change in the cathode airflow did not affect the fuel cell stack power significantly, the enormous heat capacity of the fuel cell stack drove significant hybrid system responses to the transient in a very short time. Cathode airflow was demonstrated to be an extremely important variable for thermal management in hybrid systems, and would undoubtedly play an important role in future controls development.

\section{Acknowledgments}

This work was funded by the Crosscutting Research program implemented through the U.S. Department of Energy, administered through the National Energy Technology Laboratory (NETL). The authors would like to express the gratitude to Nor Farida Harun for her effort in execution maintenance of the HyPer facility.

Also, the authors would like to acknowledge the China Scholarship Council (CSC). The authors would like to thank Biao Zhang for his helpful assistance in plotting the figures and writing.

\section{References}

[1] Massardo AF, McDonald CF, Korakianitis T. Microturbine/fuel-cell coupling for high-efficiency electrical-power generation. Journal of Engineering for Gas Turbines and Power. 2002;124:110-6. 
[2] Dennis R, Samuelsen S, Williams M, Holcombe N, Layne A. The National Energy Technology Laboratory's Hybrid Power Systems Program. ASME Turbo Expo 2002: Power for Land, Sea, and Air: American Society of Mechanical Engineers; 2002. p. 817-22.

[3] Tucker D, Ford JC, Haynes C, VanOsdol J, Liese E, Lawson L, et al. Evaluation of methods for thermal management in a coal-based SOFC turbine hybrid through numerical simulation. Journal of Fuel Cell Science and Technology. 2012;9:041004.

[4] Shelton M, Celik I, Liese E, Tucker D. A study in the process modeling of the startup of fuel cell/gas turbine hybrid systems. Journal of Engineering for Gas Turbines and Power. 2010;132:012301.

[5] Ferrari ML, Pascenti M, Magistri L, Massardo AF. Hybrid system test rig: start-up and shutdown physical emulation. Journal of Fuel Cell Science and Technology. 2010;7:021005.

[6] Jiang W, Dougal R, Fang R, Khan J. Control strategies for start-up and part-load operation of solid oxide fuel cell/gas turbine hybrid system. Journal of Fuel Cell Science and Technology. 2010;7:011016.

[7] Costamagna P, Magistri L, Massardo A. Design and part-load performance of a hybrid system based on a solid oxide fuel cell reactor and a micro gas turbine. Journal of Power Sources. 2001;96:352-68.

[8] Chan S, Ho H, Tian Y. Modelling for part-load operation of solid oxide fuel cell-gas turbine hybrid power plant. Journal of Power Sources. 2003;114:213-27.

[9] Roberts RA, Brouwer J, Samuelsen GS. Fuel cell/gas turbine hybrid system control for daily load profile and ambient condition variation. Journal of Engineering for Gas Turbines and Power. 2010;132:012302.

[10] Smith TP, Haynes CL, Wepfer WJ, Tucker D, Liese EA. Hardware-based simulation of a fuel cell turbine hybrid response to imposed fuel cell load transients. ASME 2006 International Mechanical Engineering Congress and Exposition: American Society of Mechanical Engineers; 2006. p. 319-28. 
[11] Moore JJ, Kurz R, Garcia-Hernandez A, Brun K. Experimental evaluation of the transient behavior of a compressor station during emergency shutdowns. Journal of Engineering for Gas Turbines and Power. 2010;132:062401.

[12] Kurz R, White R. Surge avoidance in gas compression systems. ASME Turbo Expo 2004: Power for Land, Sea, and Air: American Society of Mechanical Engineers; 2004. p. 735-41.

[13] Andrew PL, Yeung C-h, Cotroneo JA, Stampfli JD. Method of air-flow measurement and active operating limit line management for compressor surge avoidance. Google Patents; 2002.

[14] Hildebrandt A, Genrup M, Assadi M. Steady-State and Transient Compressor Surge Behavior Within a SOFC-GT-Hybrid System. ASME Turbo Expo 2004: Power for Land, Sea, and Air: American Society of Mechanical Engineers; 2004. p. 541-50.

[15] Pezzini P, Tucker D, Traverso A. Avoiding Compressor Surge During Emergency Shutdown Hybrid Turbine Systems. Journal of Engineering for Gas Turbines and Power. 2013;135:102602.

[16] Li Y, Weng Y. Performance study of a solid oxide fuel cell and gas turbine hybrid system designed for methane operating with non-designed fuels. Journal of Power Sources. 2011;196:3824-35.

[17] Liu J, Barnett SA. Operation of anode-supported solid oxide fuel cells on methane and natural gas. Solid State Ionics. 2003;158:11-6.

[18] Bao J, Krishnan GN, Jayaweera P, Perez-Mariano J, Sanjurjo A. Effect of various coal contaminants on the performance of solid oxide fuel cells: Part I. Accelerated testing. Journal of Power Sources. 2009;193:607-16.

[19] Comminges C, Fu Q, Zahid M, Steiner NY, Bucheli O. Monitoring the degradation of a solid oxide fuel cell stack during 10,000 h via electrochemical impedance spectroscopy. Electrochimica Acta. 2012;59:36775. 
[20] Faghri A, Guo Z. Challenges and opportunities of thermal management issues related to fuel cell technology and modeling. International Journal of Heat and Mass Transfer. 2005;48:3891-920.

[21] Tucker D, Lawson L, Smith TP, Haynes C. Evaluation of Cathodic Air Flow Transients in a Hybrid System Using Hardware Simulation. ASME 2006 4th International Conference on Fuel Cell Science, Engineering and Technology: American Society of Mechanical Engineers; 2006. p. 585-94.

[22] Tucker D, Smith T, Lawson L. Characterization of Bypass Control Methods in a Coal-Based Fuel Cell Turbine Hybrid. Proceedings of ICEPAG2006 International Colloquium on Environmentally Preferred Advanced Power Generation2006. p. 5-8.

[23] Tucker D, Lawson L, Gemmen R. Characterization of air flow management and control in a fuel cell turbine hybrid power system using hardware simulation. ASME 2005 Power Conference: American Society of Mechanical Engineers; 2005. p. 959-67.

[24] Tucker D, Liese E, VanOsdol J, Lawson L, Gemmen RS. Fuel Cell Gas Turbine Hybrid Simulation Facility Design. ASME 2002 International Mechanical Engineering Congress and Exposition: American Society of Mechanical Engineers; 2002. p. 183-90.

[25] Tucker D, Liese E, Gemmen R. Determination of the Operating Envelope for a Direct Fired Fuel Cell Turbine Hybrid Using Hardware Based Simulation. National Energy Technology Laboratory-In-house Research; 2009.

[26] Zhao F, Virkar AV. Dependence of polarization in anode-supported solid oxide fuel cells on various cell parameters. Journal of Power Sources. 2005;141:79-95.

[27] Noren D, Hoffman M. Clarifying the Butler-Volmer equation and related approximations for calculating activation losses in solid oxide fuel cell models. Journal of Power Sources. 2005;152:175-81.

[28] Hughes D, Wepfer WJ, Davies K, Ford JC, Haynes C, Tucker D. A Real-Time Spatial SOFC Model for Hardware-Based Simulation of Hybrid Systems. ASME 2011 9th International Conference on Fuel Cell 
Science, Engineering and Technology collocated with ASME 2011 5th International Conference on Energy Sustainability: American Society of Mechanical Engineers; 2011. p. 409-28.

[29] Smith TP. Hardware simulation of fuel cell/gas turbine hybrids. 2007.

[30] Hughes DO. A hardware-based transient characterization of electrochemical start-up in an SOFC/gas turbine hybrid environment using a 1-D real time SOFC model. 2011. 


\section{Figure Captions}

Fig. 1: Hybrid performance facility at NETL.

Fig. 2. Comparsion of normalized cathode inlet air mass flow transient during the hot-air valve change: (a) long time scale from $30 \%$ to $50 \%$; (b) short time scale from $30 \%$ to $50 \%$; (c) long time scale from $50 \%$ to $30 \%$; (d) short time scale from $50 \%$ to $30 \%$.

Fig. 3. Comparison of turbine speed between the coupled and decoupled tests during hot-air bypass step change from $30 \%$ to $50 \%$.

Fig. 4. Comparison of the thermal effluent transient and the turbine speed during hot-air bypass step change from $30 \%$ to $50 \%$ in coupled test: (a) long time scale; (b) short time scale.

Fig. 5. Comparison of total system pressure drop behavior in coupled and decoupled tests during hot-air bypass step change from $30 \%$ and $50 \%$.

Fig. 6. Compressor outlet pressure, cathode inlet pressure and turbine inlet pressure responses during hot-air bypass step change from 30\% and 50\%: (a) coupled test; (b) decoupled test

Fig. 7. Cathode inlet temperature, turbine inlet temperature and turbine outlet temperature responses during hot-air bypass step change from 30\% and 50\%: (a) coupled test; (b) decoupled test

Fig. 8. The change in the dissipation of thermal energy in fuel cell stack in coupled test during hot-air bypass step change from $30 \%$ and 50\%: (a) long time scale; (b) short time scale.

Fig. 9. Average temperature of air and solid in coupled test during hot-air bypass step change from 30\% and 50\%: (a) short time scale; (b) normalized value.

Fig. 10. Multiple variables response in coupled test during hot-air bypass step change from $30 \%$ and $50 \%$ : (a) original value; (b) normalized value.

Fig. 11. Voltage, stack power and fuel utilization in coupled test during hot-air bypass step change from $30 \%$ and $50 \%$. 


\section{Table Captions}

Table 1: Initial state before switching to HILS

Table 2: Test procedure

Table 3: Nominal value and maximum error allowed in the process variable

Table 4: Transfer functions in coupled and decoupled tests

Table 5: Dead time for each variable

Table 6: Time constant for each variable 


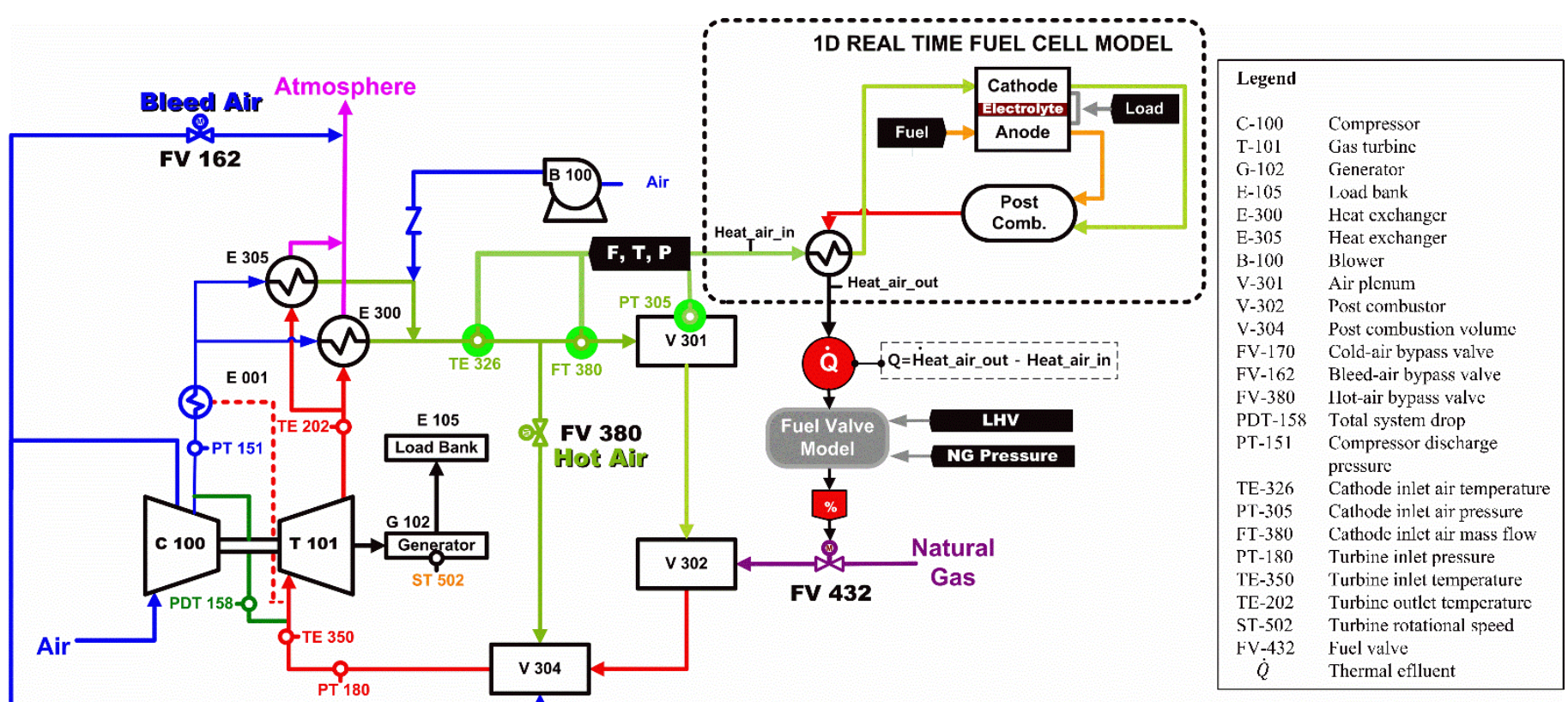




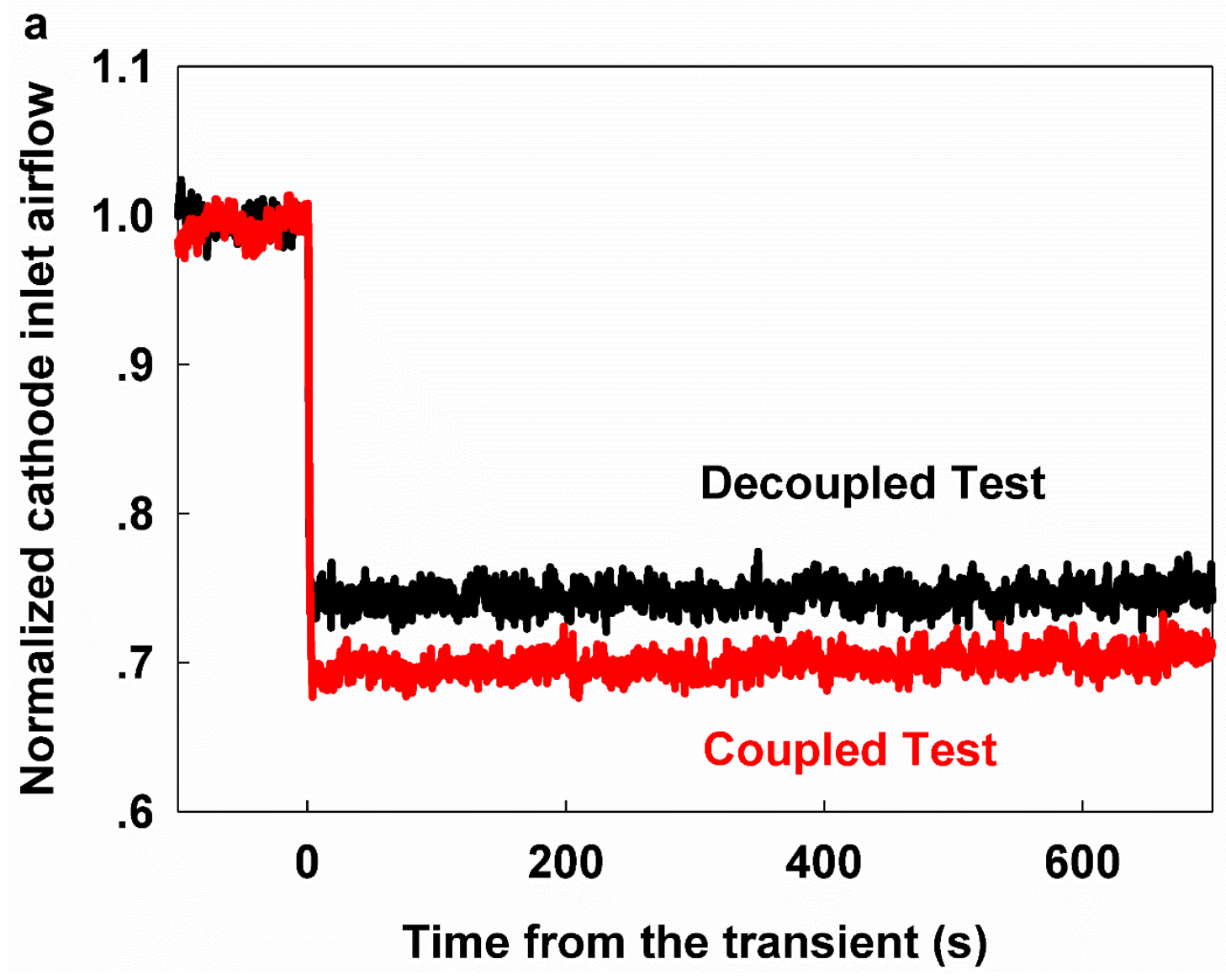




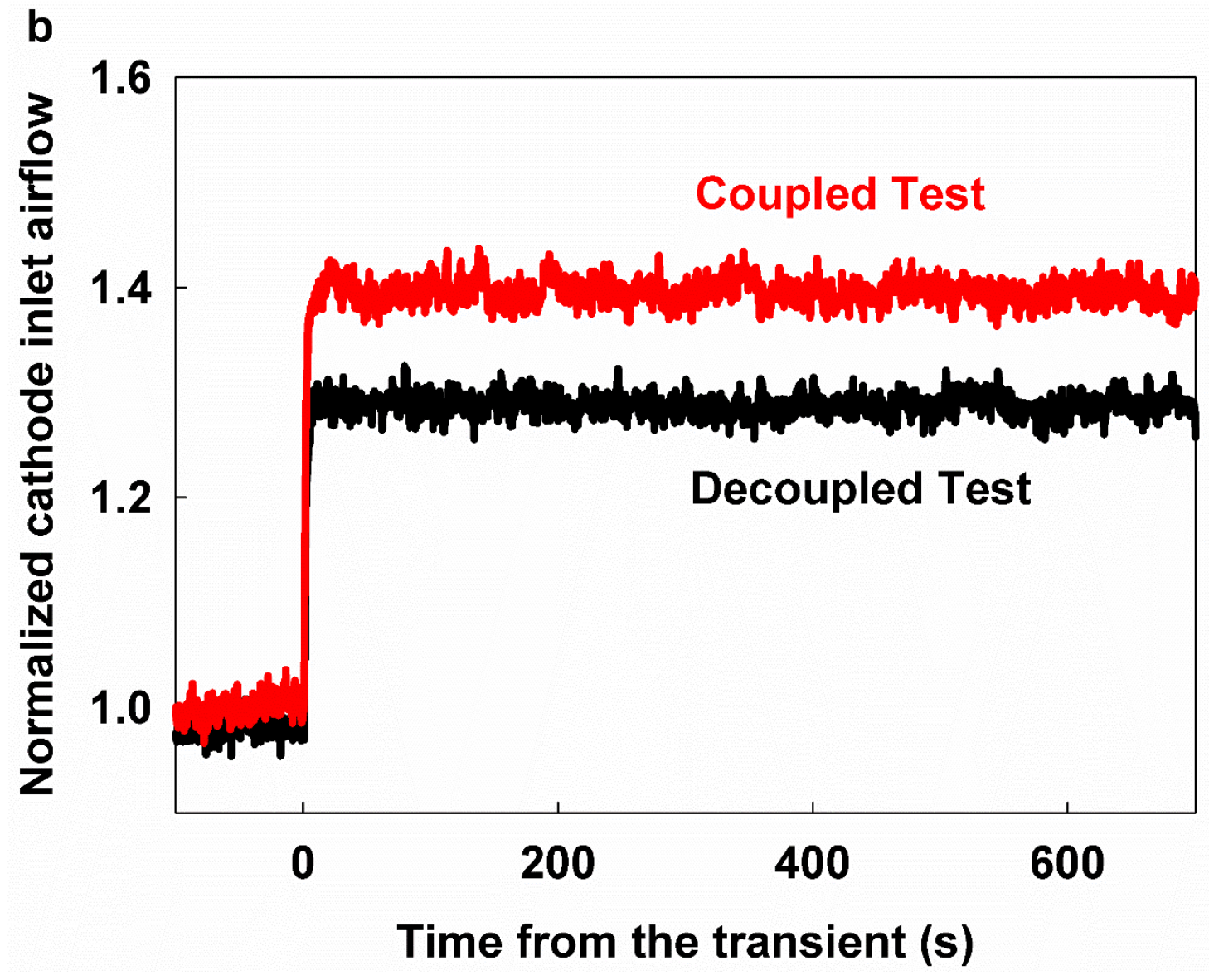




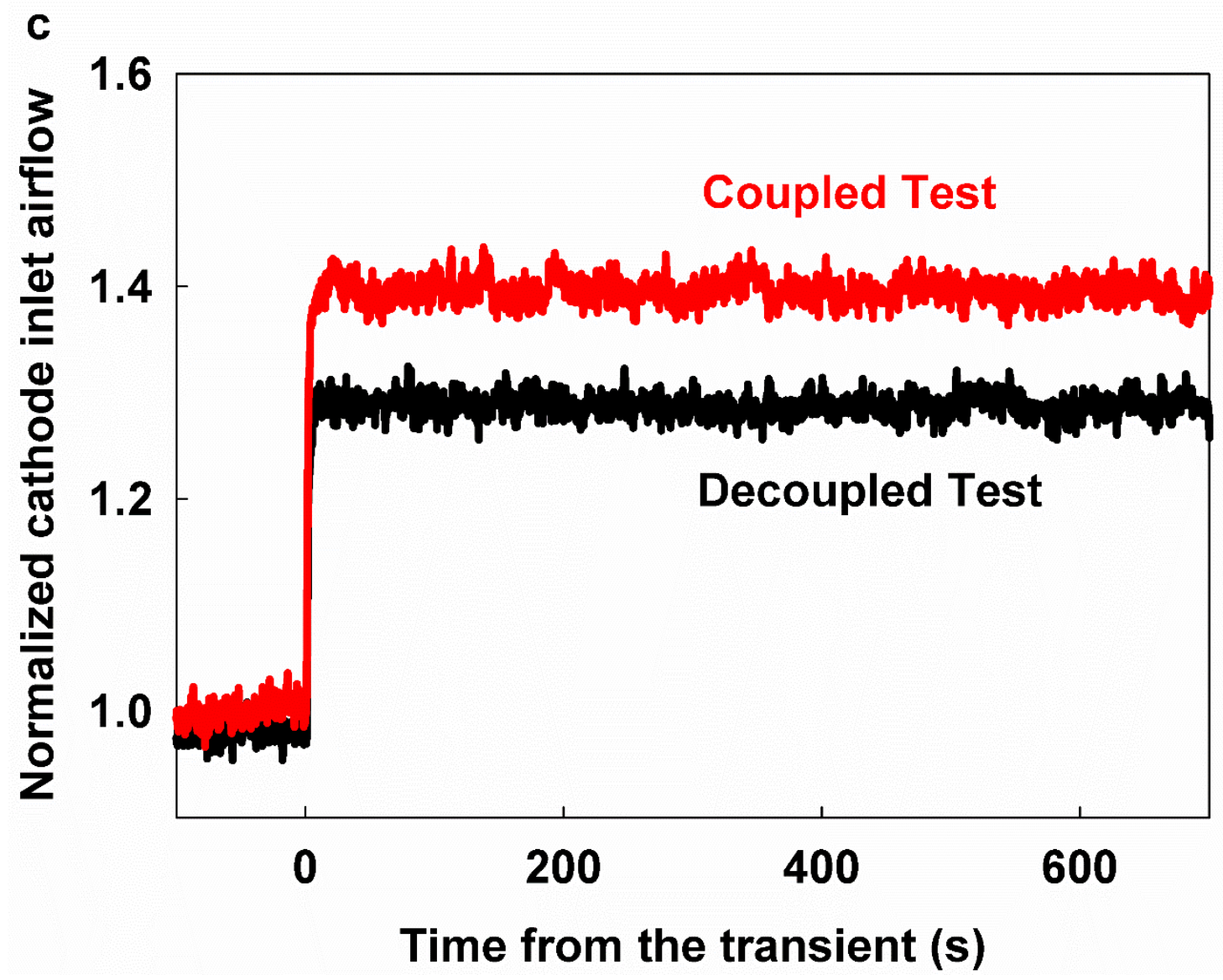




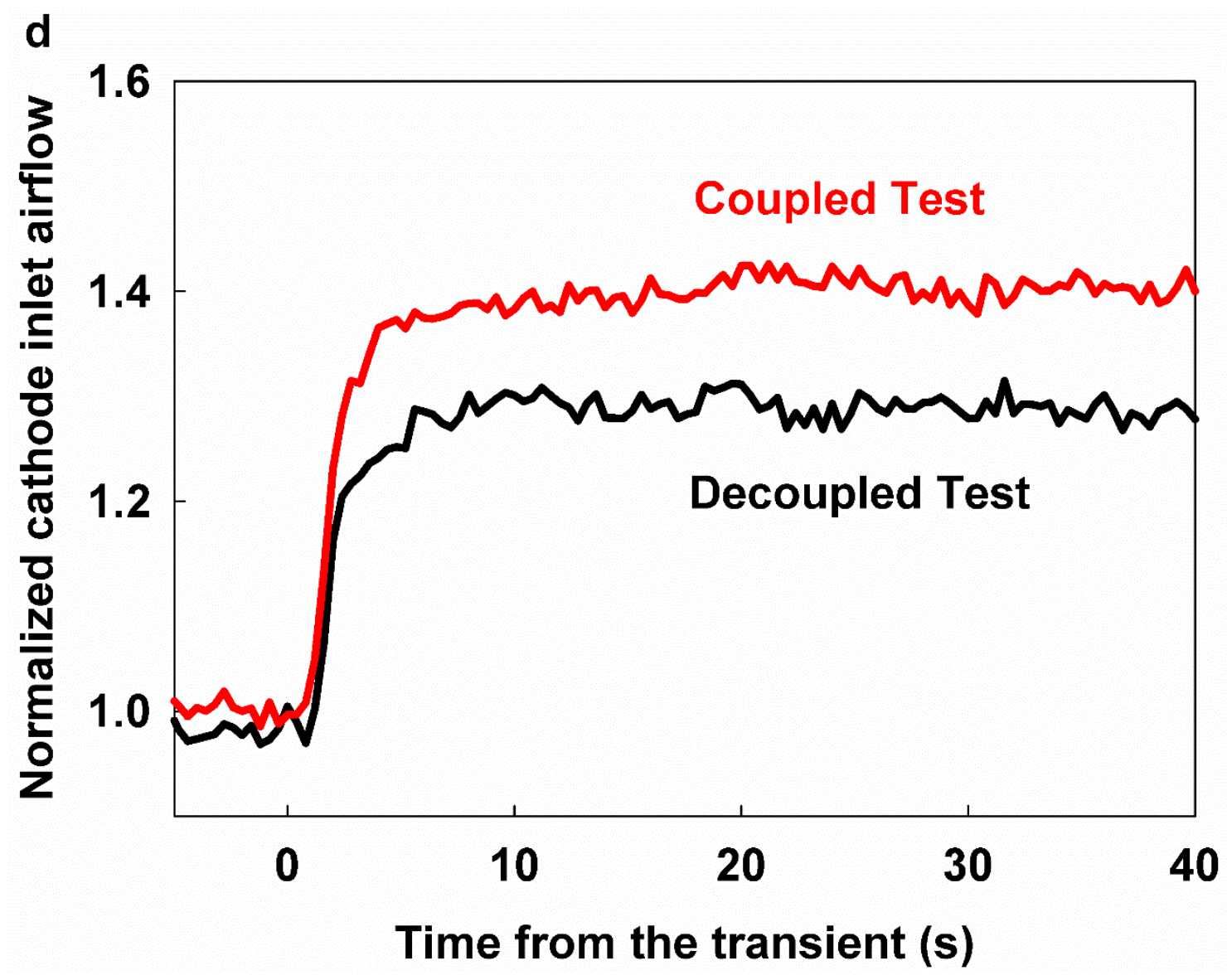




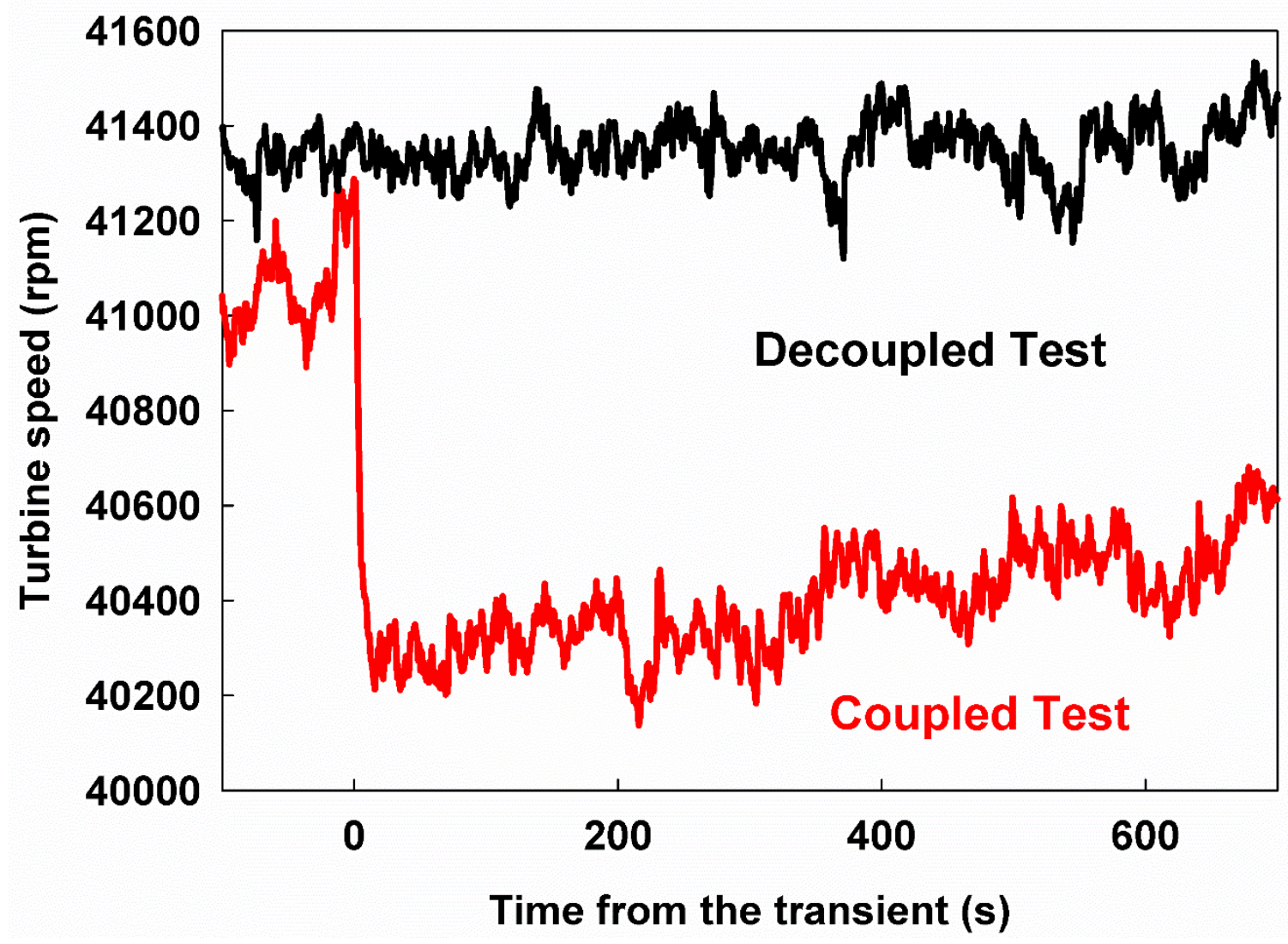




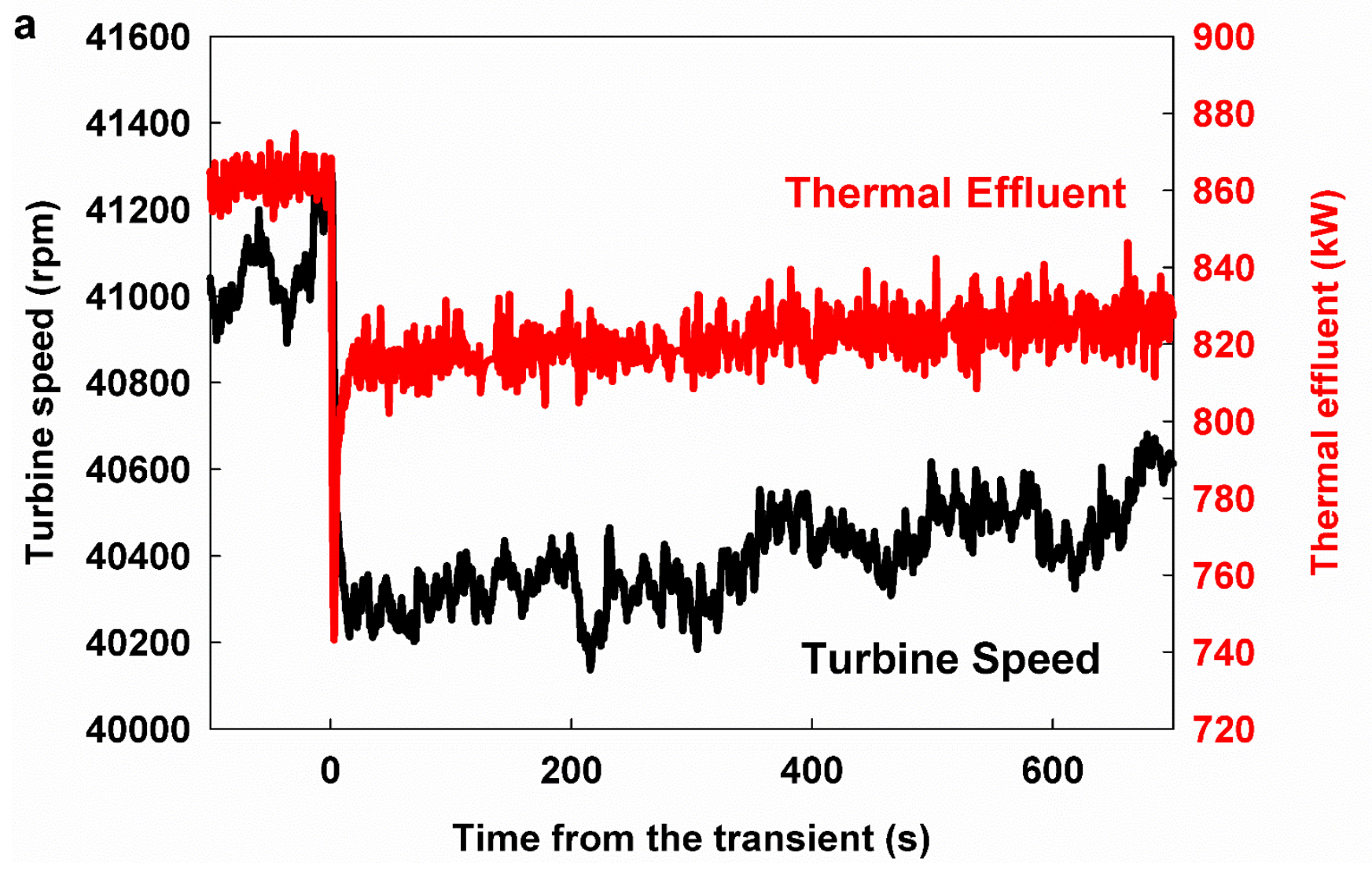




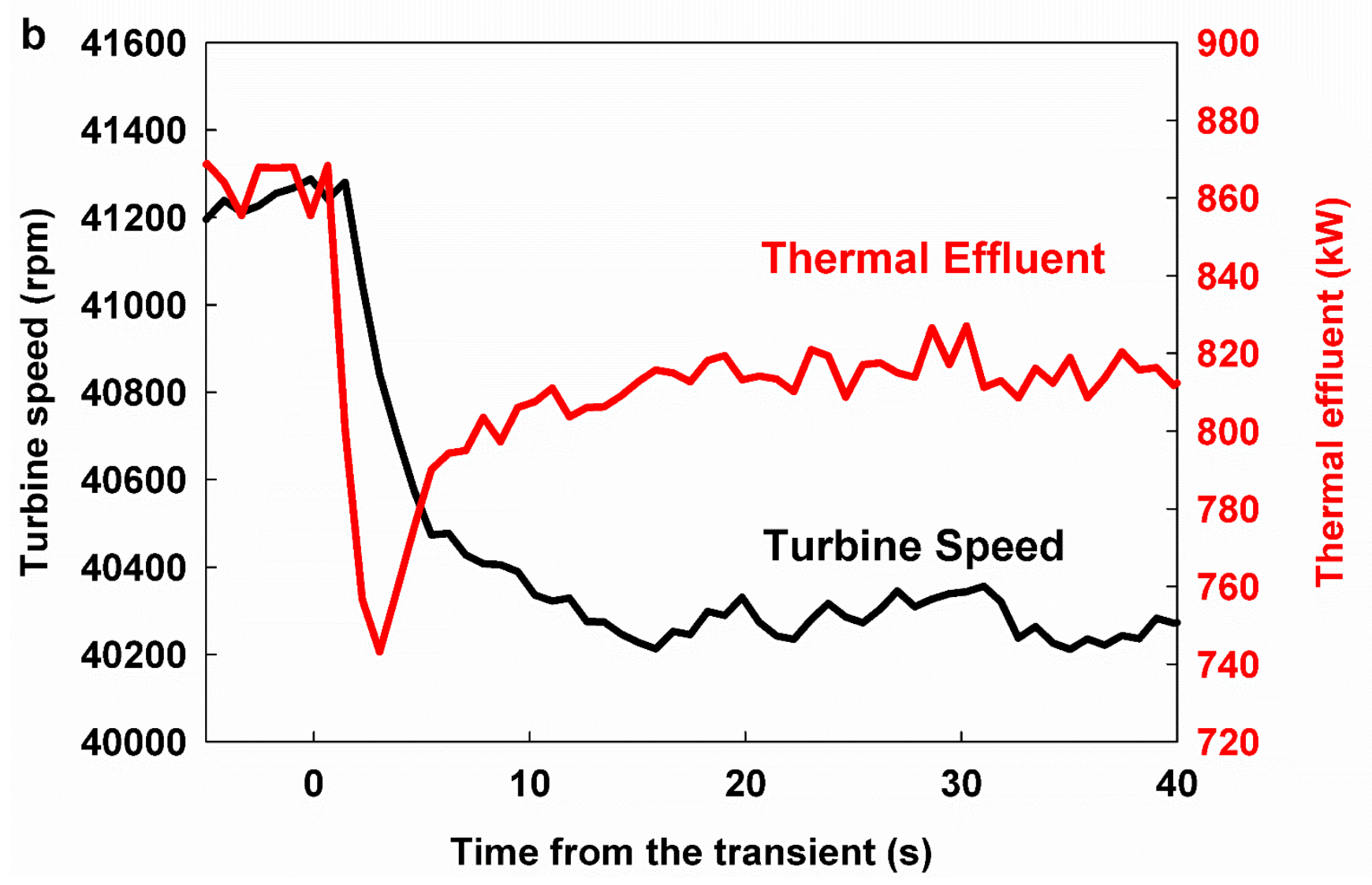




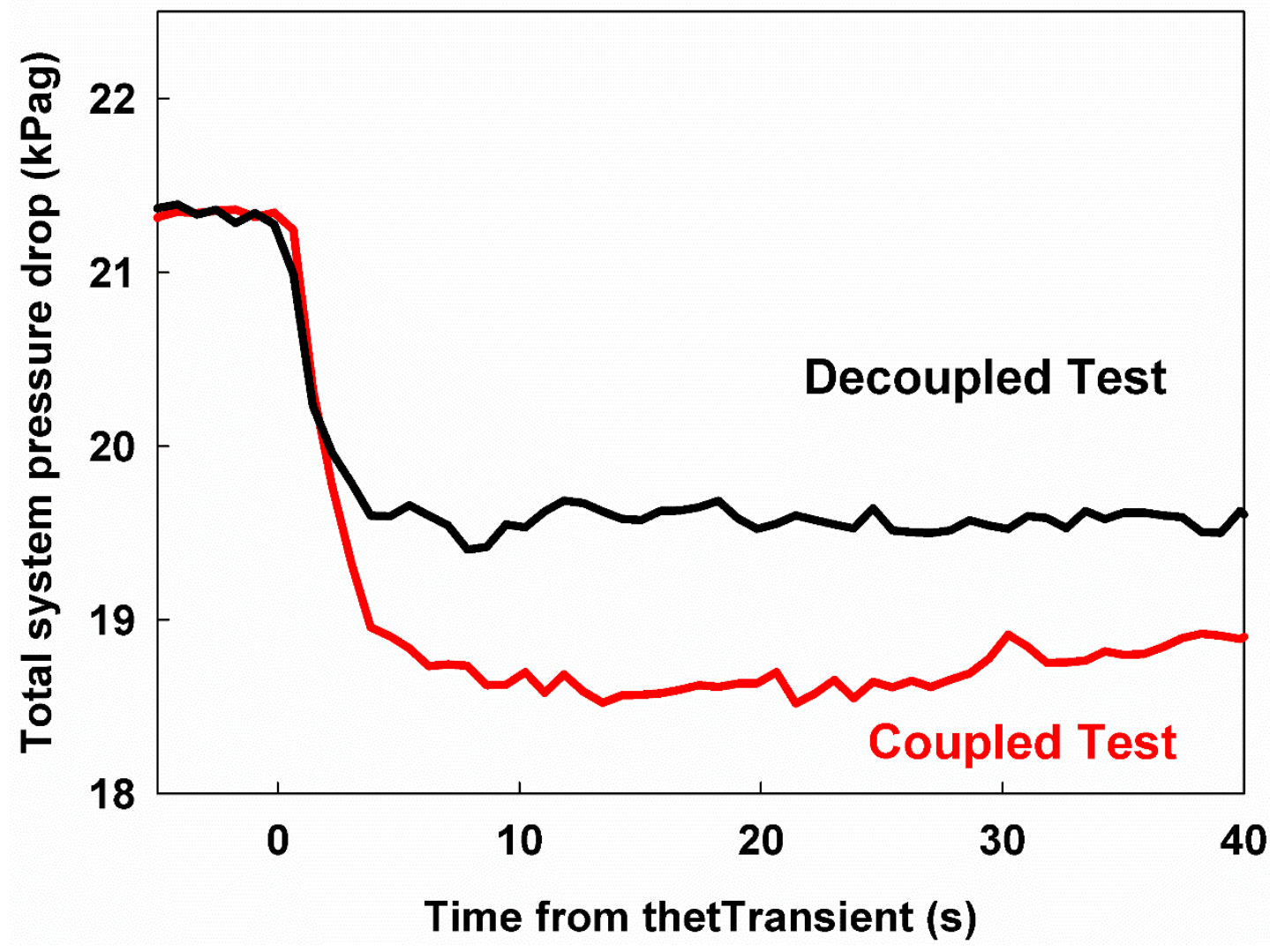




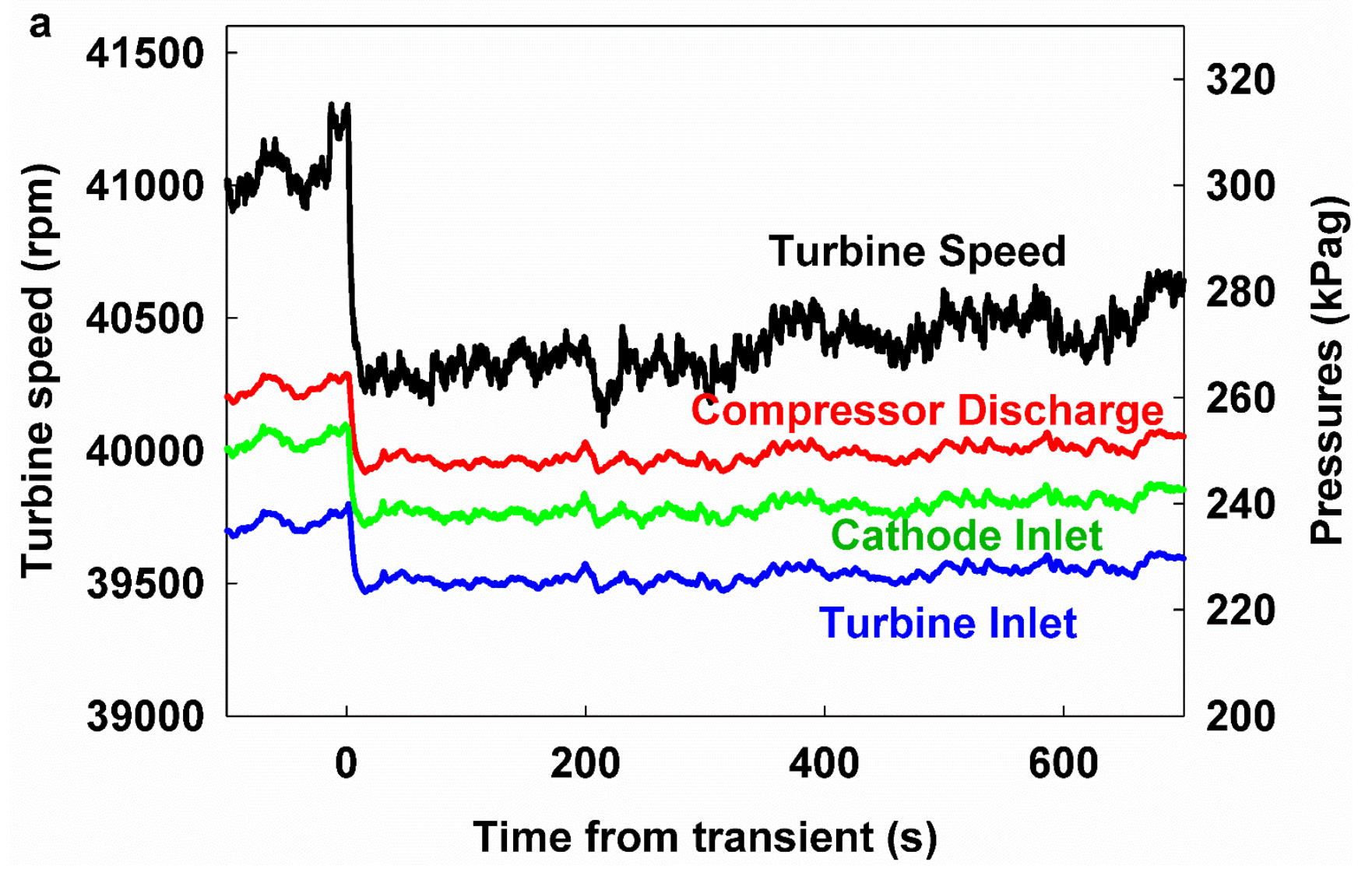




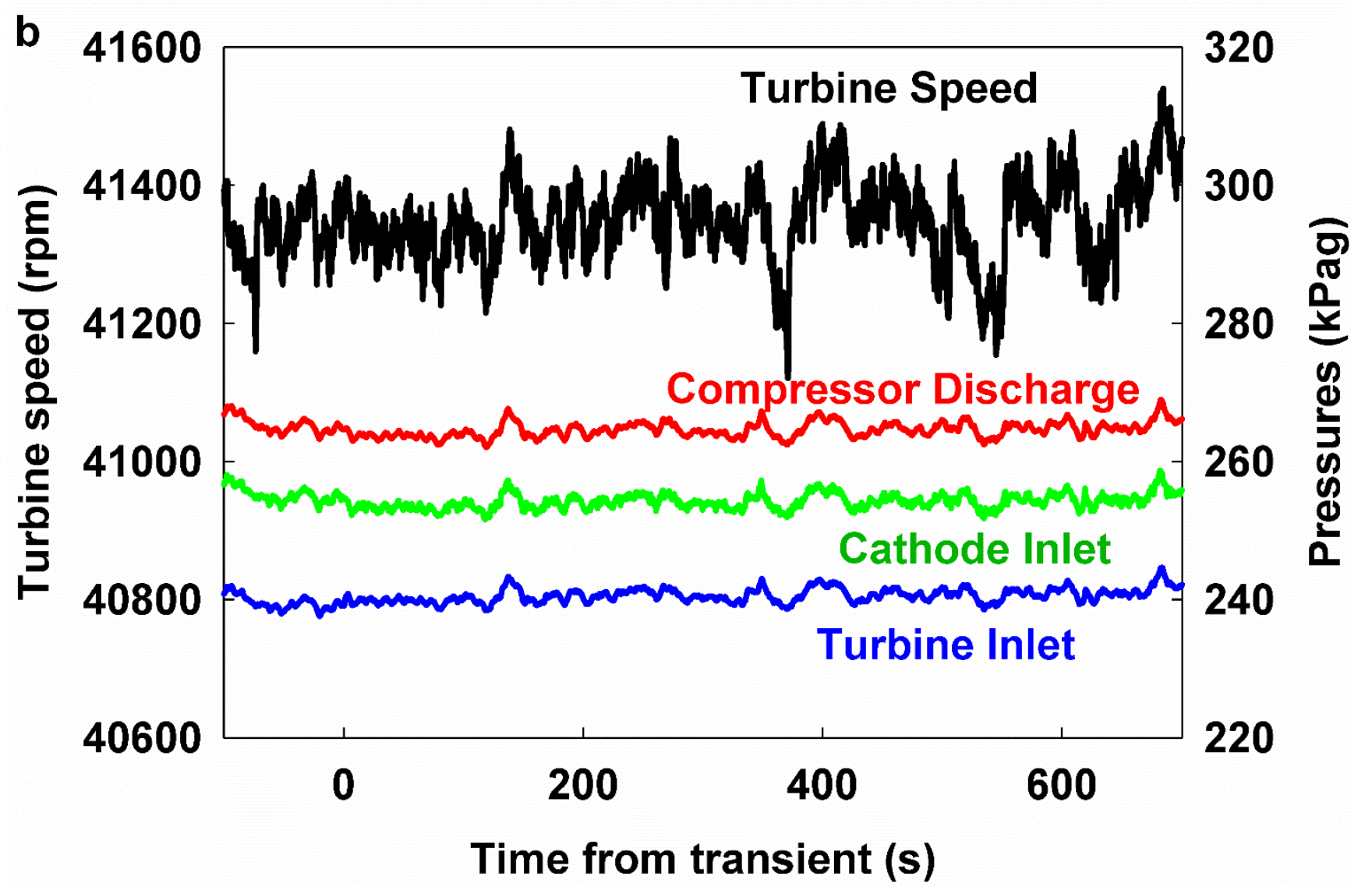




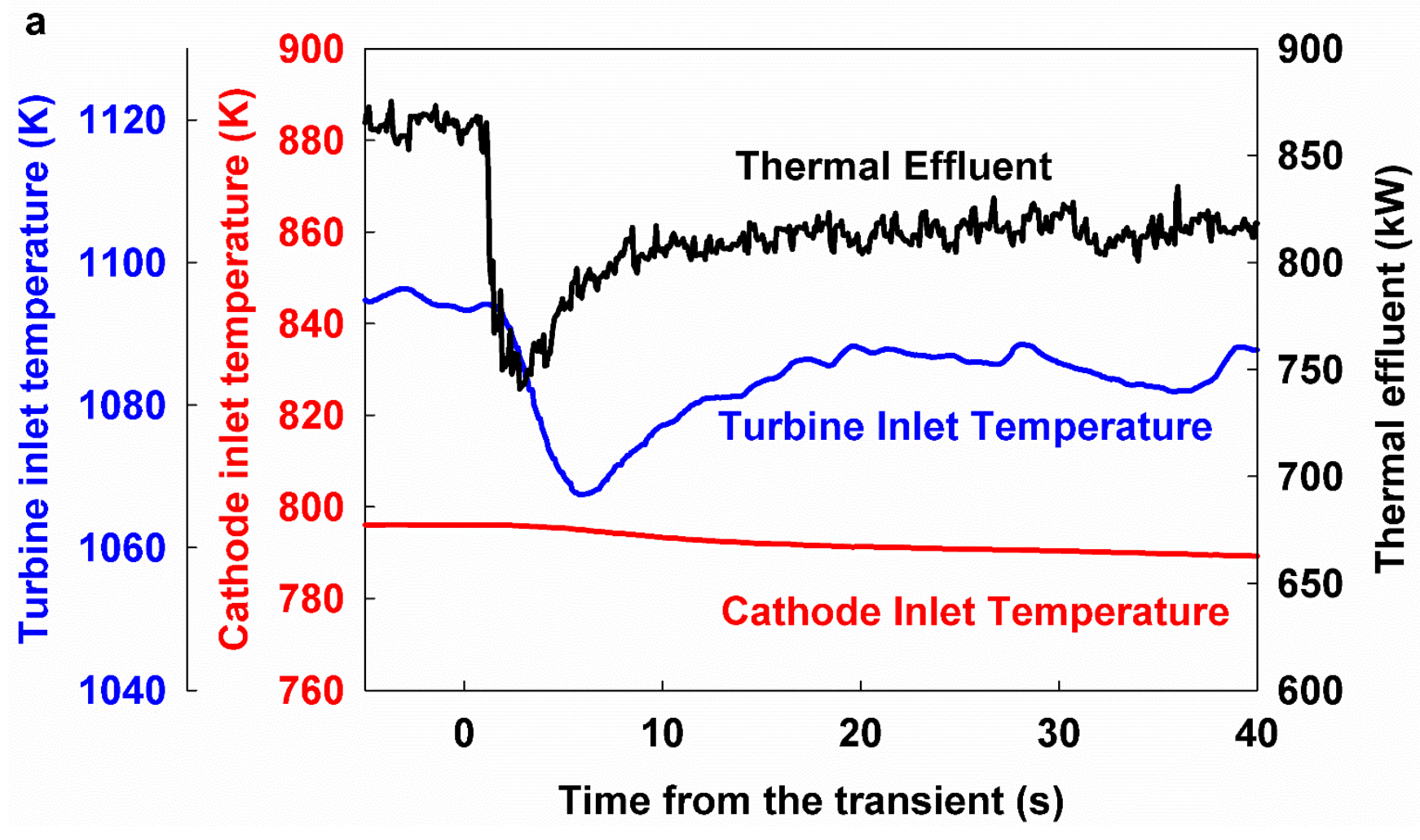




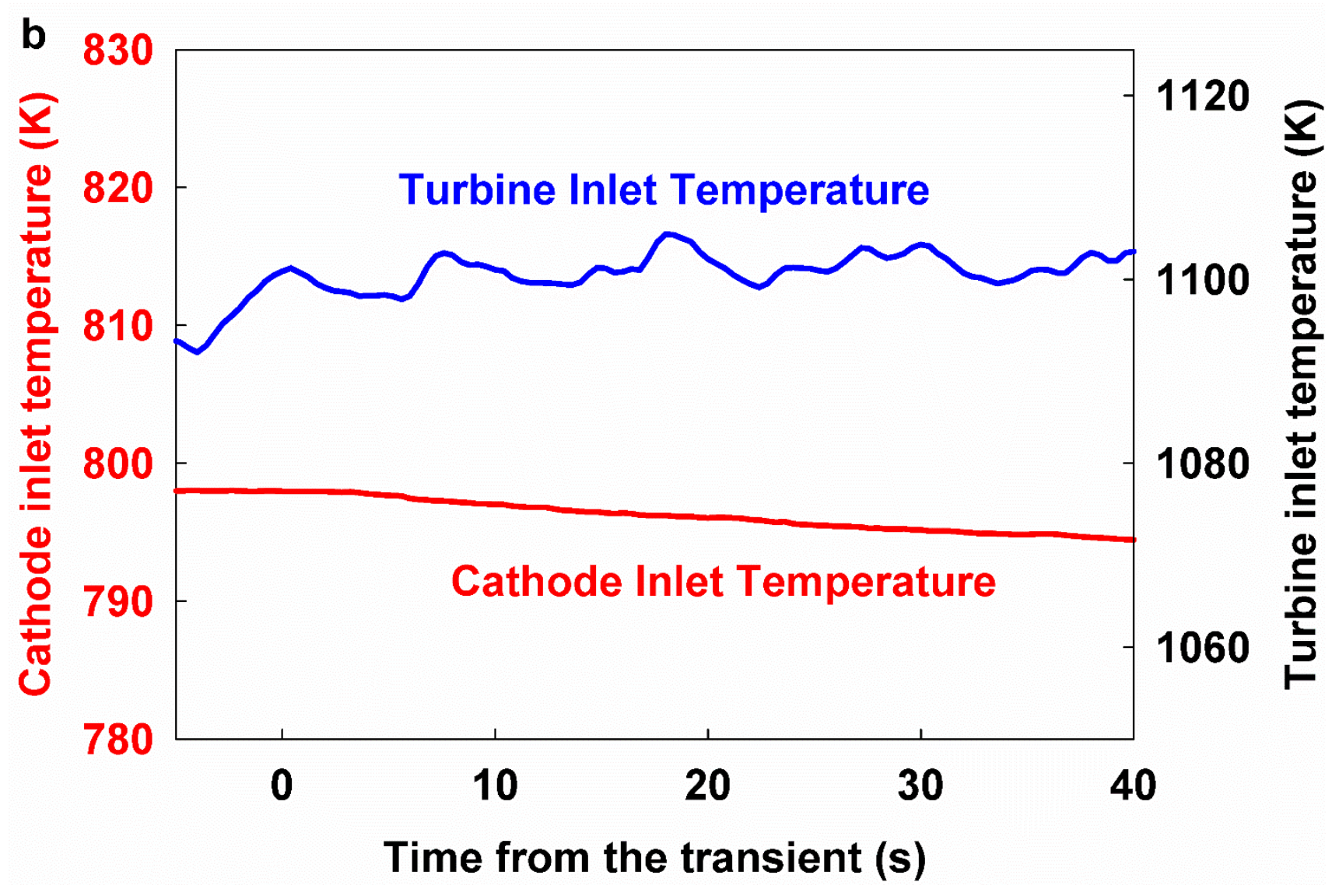


a

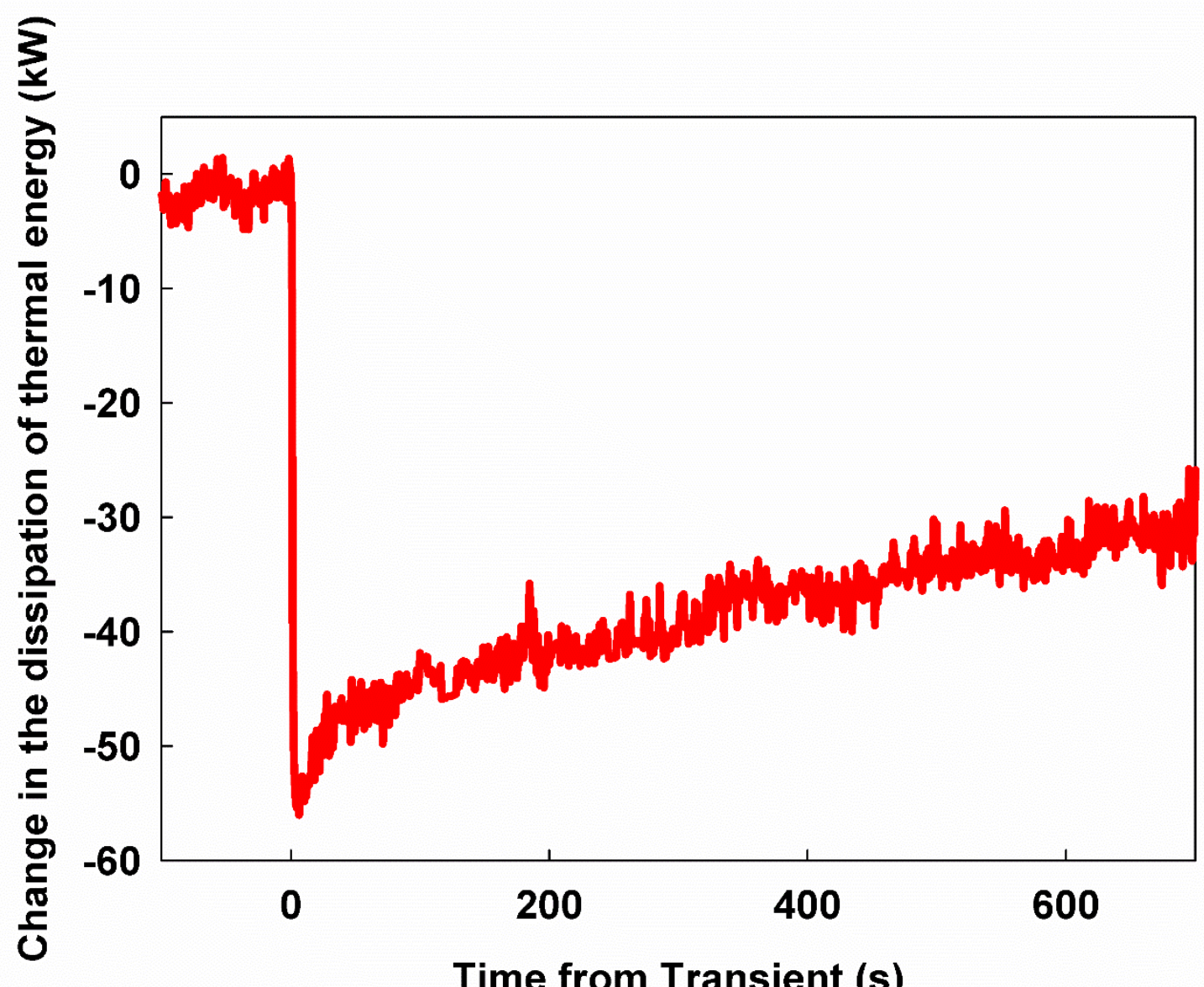

Time from Transient (s) 


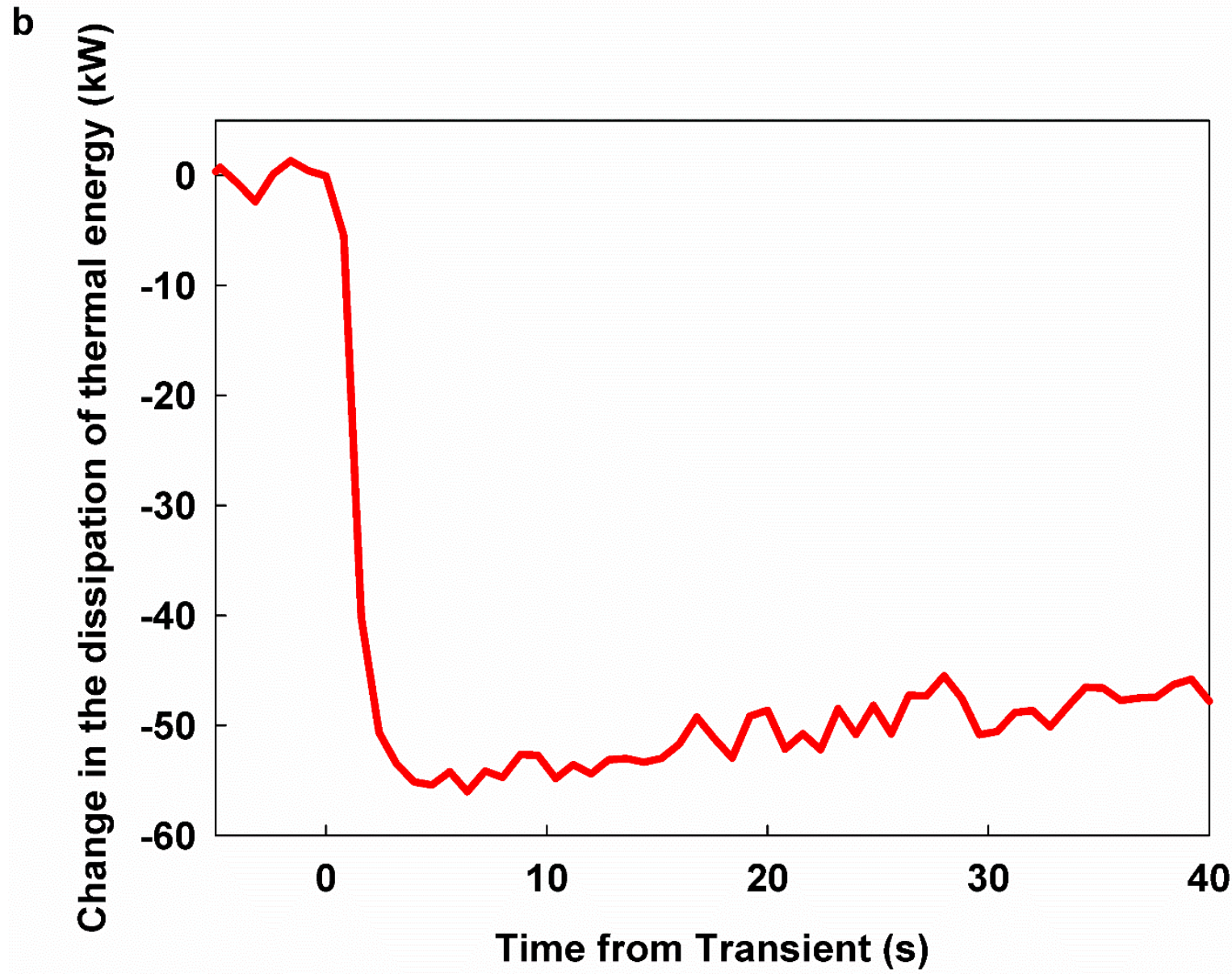


a

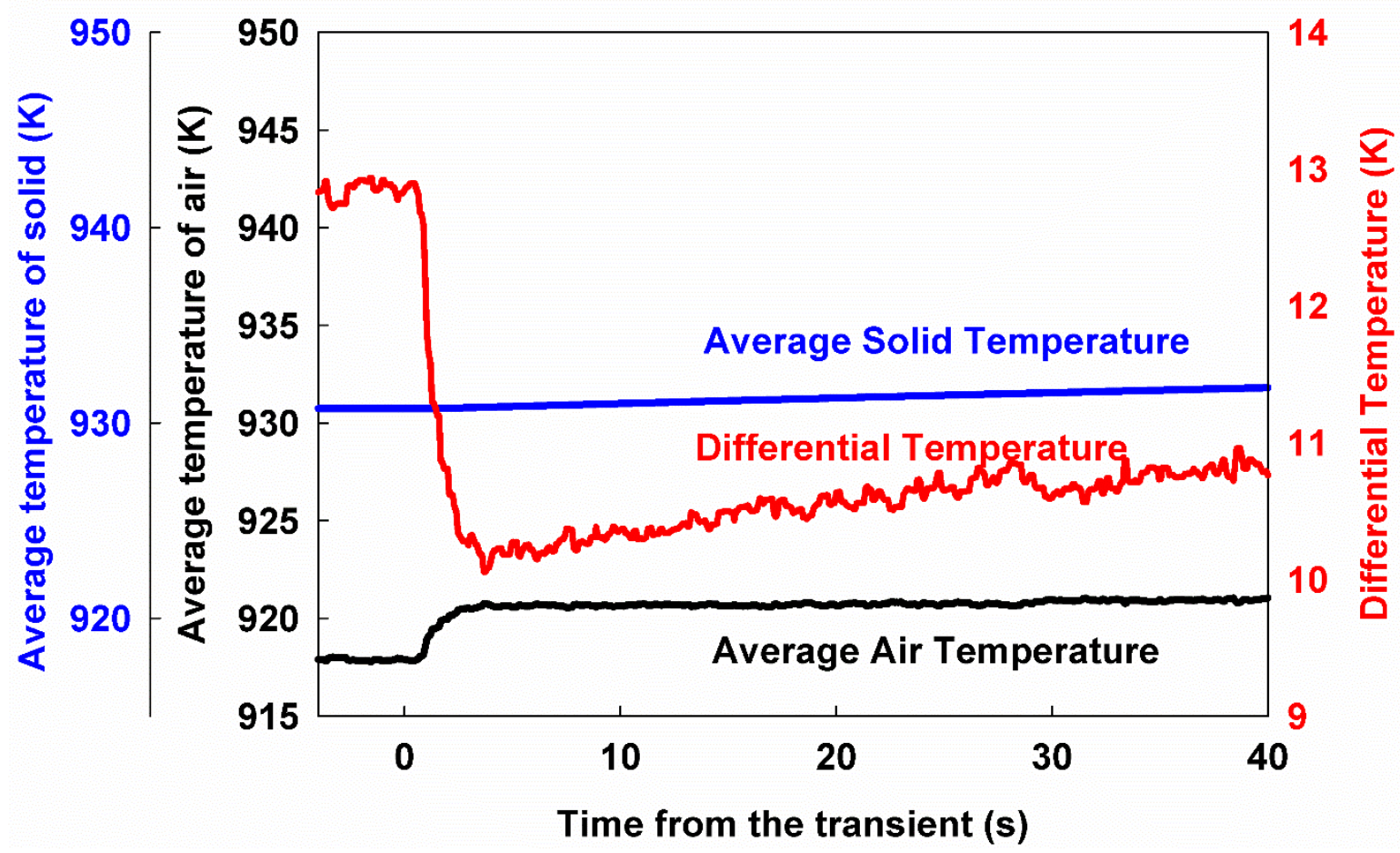




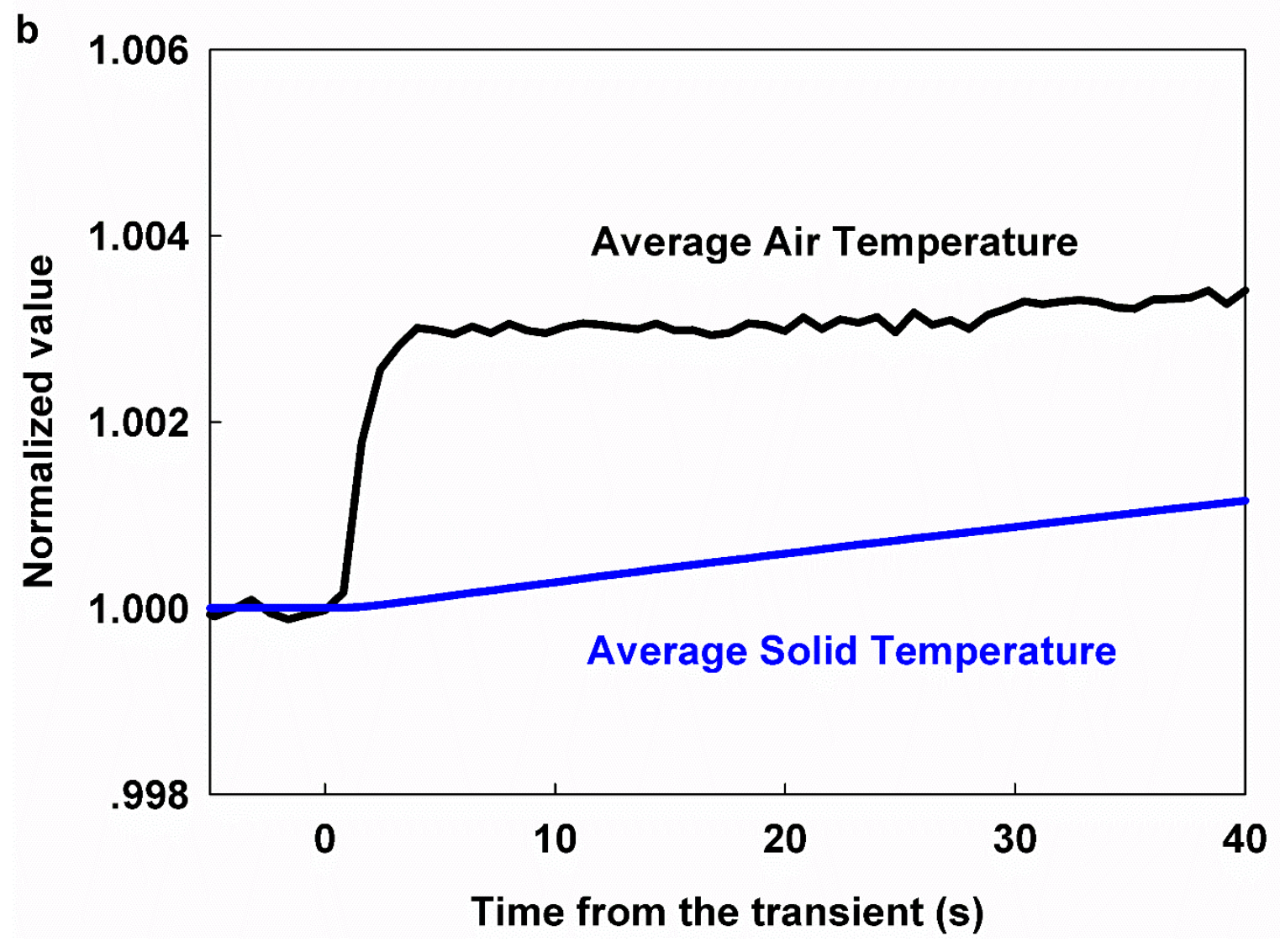



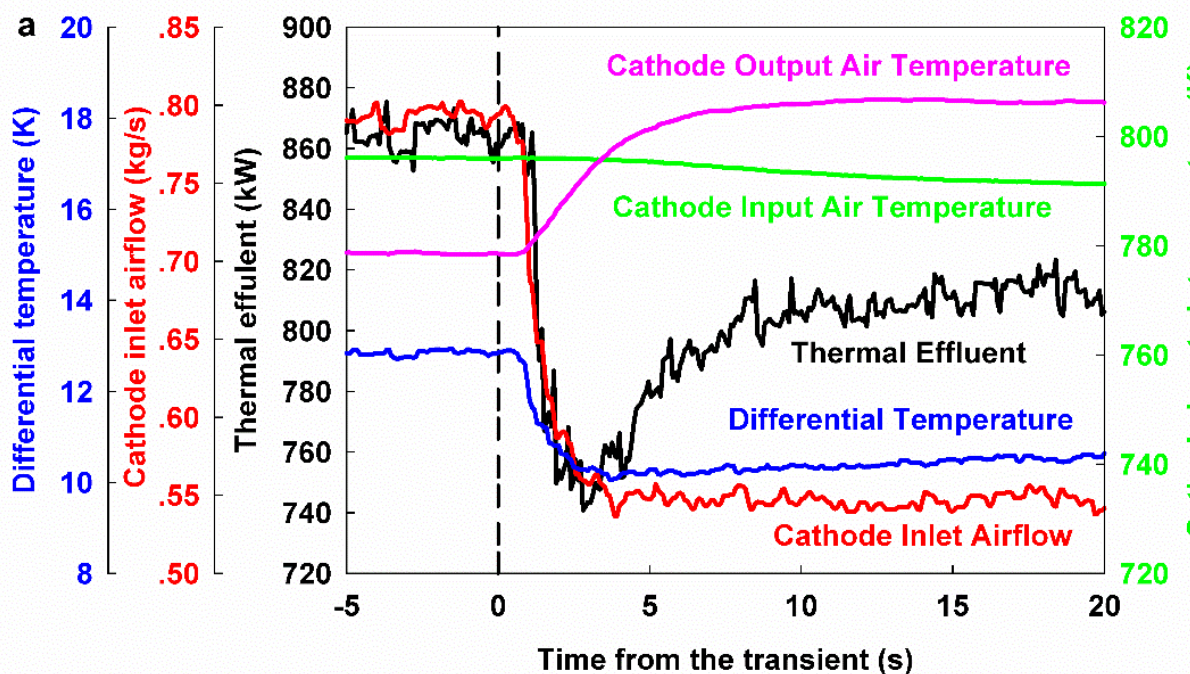

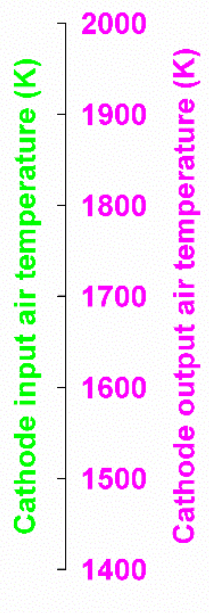




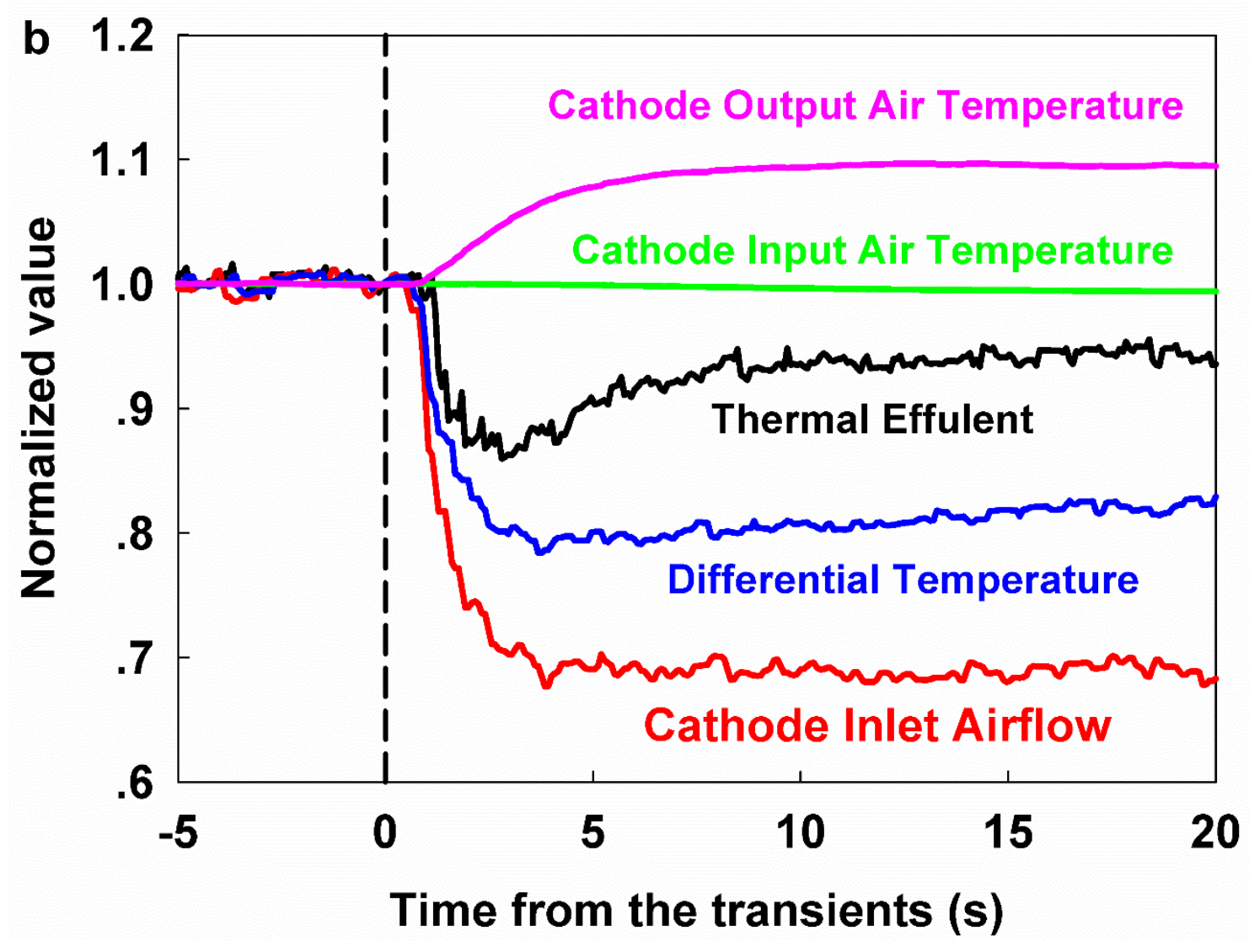




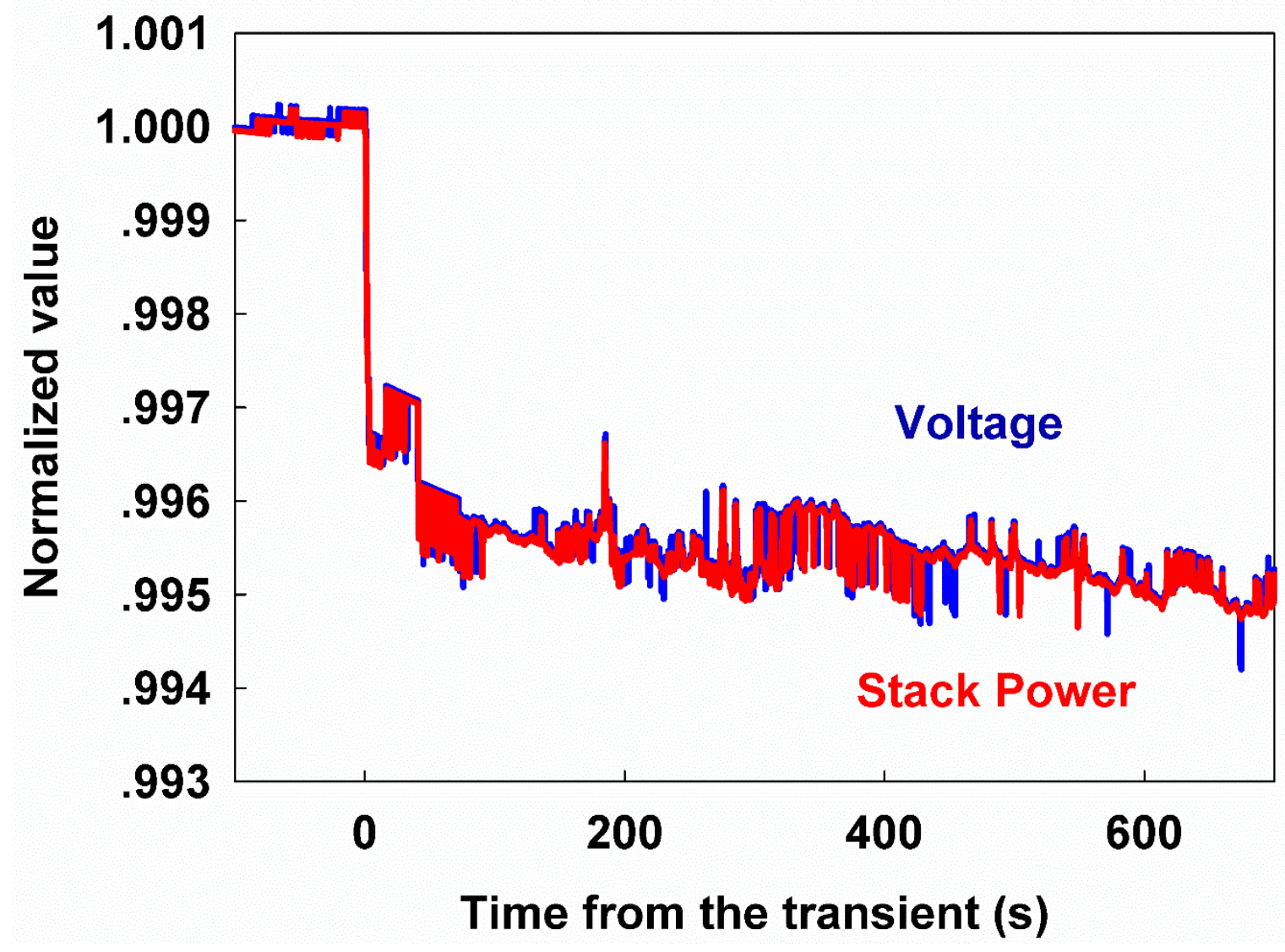




\section{Tables}

\section{Table 1}

Initial state before switching to HILS.

Fuel cell input parameter

Fuel cell load

Number of cells

Initial fuel cell temperature

Inlet air mass flow rate

Inlet air temperature

Inlet air pressure

Inlet fuel composition

Inlet fuel mass flow rate

Inlet fuel temperature

Inlet fuel pressure
$275 \mathrm{~A}$

2000

$1073.15 \mathrm{~K}$

$0.78 \mathrm{~kg} / \mathrm{s}$

$793.95 \mathrm{~K}$

$251 \mathrm{kPag}$

$20 \% \mathrm{H}_{2} \mathrm{O}, 80 \% \mathrm{H}_{2}$

$34.2 \mathrm{~g} / \mathrm{s}$

$1073.15 \mathrm{~K}$

$243 \mathrm{kPag}$

\section{Corresponding hardware conditions}

Turbine electrical load

Hot-air bypass valve

Cold-air bypass valve

Bleed-air bypass valve
$45 \mathrm{~kW}$

$30 \%$ open

$40 \%$ open

$90 \%$ closed 
Fuel valve

$51.5 \%$ open 
Table 2

Test procedure.

\begin{tabular}{c|ccc}
\hline \multirow{2}{*}{} & \multicolumn{3}{c}{ Coupled Test } \\
\cline { 2 - 4 } & Hot-air bypass FV-380 & Cathode airflow FT-380 & Fuel valve FV-432 \\
\hline Initial value & $30 \%$ open & $0.78 \mathrm{~kg} / \mathrm{s}$ & Controlled by FCM \\
First step & $50 \%$ open & $0.55 \mathrm{~kg} / \mathrm{s}$ & Controlled by FCM \\
Second step & $30 \%$ open & $0.78 \mathrm{~kg} / \mathrm{s}$ & Controlled by FCM \\
\hline \multirow{2}{*}{$\begin{array}{c}\text { First step } \\
\text { Second step }\end{array}$} & Hot-air bypass FV-380 & Cathode airflow FT-380 & Fuel valve FV-432 \\
\cline { 2 - 4 } & $30 \%$ open & $0.78 \mathrm{~kg} / \mathrm{s}$ & $51.5 \%$ open \\
& $50 \%$ open & $0.58 \mathrm{~kg} / \mathrm{s}$ & $51.5 \%$ open \\
& $30 \%$ open & $0.78 \mathrm{~kg} / \mathrm{s}$ & $51.5 \%$ open \\
\hline
\end{tabular}




\section{Table 3}

Nominal value and maximum error allowed in the process variable.

\begin{tabular}{c|cc}
\hline Process variable & Nominal value & Maximum perturbation allowed \\
\hline Cathode inlet mass flow & $1.0[\mathrm{~kg} / \mathrm{s}]$ & $0.4[\mathrm{~kg} / \mathrm{s}]$ \\
Turbine speed & $40,500[\mathrm{rpm}]$ & $2,000[\mathrm{rpm}]$ \\
Thermal effluent & $873.4[\mathrm{~kW}]$ & $240[\mathrm{~kW}]$ \\
Total system pressure drop & $21.3[\mathrm{kPag}]$ & $5[\mathrm{kPag}]$ \\
Cathode inlet temperature & $795.9[\mathrm{~K}]$ & $24[\mathrm{~K}]$ \\
Change in dissipation of thermal & & $110[\mathrm{~kW}]$ \\
energy & $-0.62[\mathrm{~kW}]$ & $6[\mathrm{~K}]$ \\
\hline
\end{tabular}


Table 4 Transfer functions in coupled and decoupled tests when opening and closing the hot-air bypass valve.

\begin{tabular}{|c|c|c|c|c|c|c|c|c|}
\hline \multirow{3}{*}{ Variables } & \multicolumn{4}{|c|}{ Hot-air bypass valve from $30 \%$ to $50 \%$} & \multicolumn{4}{|c|}{ Hot-air bypass valve from $50 \%$ to $30 \%$} \\
\hline & \multicolumn{2}{|c|}{ Coupled } & \multicolumn{2}{|c|}{ Decoupled } & \multicolumn{2}{|c|}{ Coupled } & \multicolumn{2}{|c|}{ Decoupled } \\
\hline & Down & Up & & & Up & Down & & \\
\hline $\begin{array}{l}\text { Cathode inlet } \\
\text { mass flow }\end{array}$ & \multicolumn{2}{|c|}{$G(s)=\frac{-0.03 e^{-0.4 s}}{(1.6 s+1)}$} & \multicolumn{2}{|c|}{$G(s)=\frac{-0.025 e^{-0.5 s}}{(1.3 s+1)}$} & \multicolumn{2}{|c|}{$G(s)=\frac{-0.0275 e^{-0.6 s}}{(2 s+1)}$} & \multicolumn{2}{|c|}{$G(s)=\frac{-0.0225 e^{-0.7 s}}{(2.1 s+1)}$} \\
\hline Turbine speed & \multicolumn{2}{|c|}{$G(s)=\frac{-0.02 \cdot e^{-1.6 s}}{(4 s+1)}$} & \multicolumn{2}{|c|}{ N/A } & \multicolumn{2}{|c|}{$G(s)=\frac{-0.02 e^{-1.4 s}}{(3 s+1)}$} & \multicolumn{2}{|c|}{ N/A } \\
\hline $\begin{array}{l}\text { Thermal } \\
\text { effluent }\end{array}$ & $G(s)=\frac{-0.025 e^{-1.1 s}}{(1.6 s+1)}$ & $G(s)=\frac{0.015 e^{-0.4 s}}{(5.6 s+1)}$ & $\mathrm{N} / \mathrm{A}$ & N/A & $G(s)=\frac{-0.023 e^{-1 s}}{(2 s+1)}$ & $G(s)=\frac{0.0125 e^{-0.4 s}}{(2.8 s+1)}$ & N/A & N/A \\
\hline $\begin{array}{l}\text { Total system } \\
\text { pressure drop }\end{array}$ & \multicolumn{2}{|c|}{$G(s)=\frac{-0.027 e^{-0.4 s}}{(2.5 s+1)}$} & \multicolumn{2}{|c|}{$G(s)=\frac{-0.017 e^{-0.1 s}}{(1.6 s+1)}$} & \multicolumn{2}{|c|}{$G(s)=\frac{-0.0255 e^{-0.5 s}}{(4 s+1)}$} & \multicolumn{2}{|c|}{$G(s)=\frac{-0.016 e^{-0.4 s}}{(3.4 s+1)}$} \\
\hline $\begin{array}{l}\text { Cathode inlet } \\
\text { temperature }\end{array}$ & \multicolumn{2}{|c|}{$G(s)=\frac{-0.0235 e^{-2 s}}{(45 s+1)}$} & \multicolumn{2}{|c|}{$G(s)=\frac{-0.025 e^{-2.5 s}}{(60 s+1)}$} & \multicolumn{2}{|c|}{$G(s)=\frac{-0.025 e^{-1.5 s}}{(55 s+1)}$} & \multicolumn{2}{|c|}{$G(s)=\frac{-0.0255 e^{-1.2 s}}{(35 s+1)}$} \\
\hline $\begin{array}{l}\text { Change in } \\
\text { dissipation }\end{array}$ & \multicolumn{2}{|c|}{$G(s)=\frac{0.025 e^{-0.6 s}}{(1.4 s+1)}$} & \multicolumn{2}{|c|}{ N/A } & \multicolumn{2}{|c|}{$G(s)=\frac{-0.025 e^{-0.7 s}}{(2 s+1)}$} & \multicolumn{2}{|c|}{ N/A } \\
\hline $\begin{array}{l}\text { Differential } \\
\text { temperature }\end{array}$ & $G(s)=\frac{-0.023 e^{-0.5 s}}{(1.6 s+1)}$ & $G(s)=\frac{-0.017 e^{-8 s}}{(125 s+1)}$ & N/A & N/A & $G(s)=\frac{-0.021 e^{-0.65 s}}{(1.9 s+1)}$ & $G(s)=\frac{0.011 e^{-8 s}}{(125 s+1)}$ & N/A & N/A \\
\hline
\end{tabular}




\section{Table 5}

Dead time for each variable.

\begin{tabular}{c|c|cccc}
\hline \multirow{2}{*}{ Order } & \multirow{2}{*}{ Variables } & \multicolumn{2}{|c}{ Hot-air valve from $\mathbf{3 0 \%}$ to $\mathbf{5 0 \%}$} & \multicolumn{2}{c}{ Hot-air-valve from $\mathbf{5 0 \%}$ to $\mathbf{3 0 \%}$} \\
\cline { 3 - 6 } & & Coupled & Decoupled & Coupled & Decoupled \\
\hline 1 & Total system pressure drop & 0.4 & 0.1 & 0.5 & 0.4 \\
2 & Cathode inlet mass flow & 0.4 & 0.5 & 0.6 & 0.7 \\
3 & Differential temperature & 0.5 & N/A & 0.65 & N/A \\
4 & Change in dissipation & 0.6 & N/A & 0.7 & N/A \\
5 & Thermal effluent & 1.1 & N/A & 1 & N/A \\
6 & Turbine speed & 1.6 & N/A & 1.4 & N/A \\
7 & Cathode inlet temperature & 2 & 2.5 & 1.5 & 1.2 \\
\hline
\end{tabular}




\section{Table 6}

Time constant for each variable.

\begin{tabular}{c|c|cccc}
\hline \multirow{2}{*}{ Order } & \multirow{2}{*}{ Variables } & \multicolumn{2}{c}{ Hot-air valve from $\mathbf{3 0 \%}$ to $\mathbf{5 0 \%}$} & \multicolumn{2}{c}{ Hot-air-valve from $\mathbf{5 0 \%}$ to $\mathbf{3 0 \%}$} \\
\cline { 3 - 5 } & & Coupled & Decoupled & Coupled & Decoupled \\
\hline 1 & Change in dissipation & 1.4 & N/A & 2 & N/A \\
2 & Differential temperature & 1.6 & N/A & 1.9 & N/A \\
3.1 & Cathode inlet mass flow & 1.6 & 1.3 & 2 & 2.1 \\
3.2 & Thermal effluent & 1.6 & N/A & 2 & N/A \\
4 & Total system pressure drop & 2.5 & 1.6 & 4 & 3.4 \\
5 & Turbine speed & 4 & N/A & 3 & N/A \\
6 & Cathode inlet temperature & 45 & 60 & 55 & 35 \\
\hline
\end{tabular}

